ATOLL RESEARCH BULLETIN

NO. 467

A GENERAL BIOLOGICAL AND GEOLOGICAL SURVEY OF THE RIMS OF PONDS IN THE MAJOR MANGROVE ISLANDS OF THE PELICAN CAYS, BELIZE

BY

IAN G. MACINTYRE, IVAN GOODBODY, KLAUS RÜTZLER, DIANE S. LITTLER, AND MARK M. LITTLER 

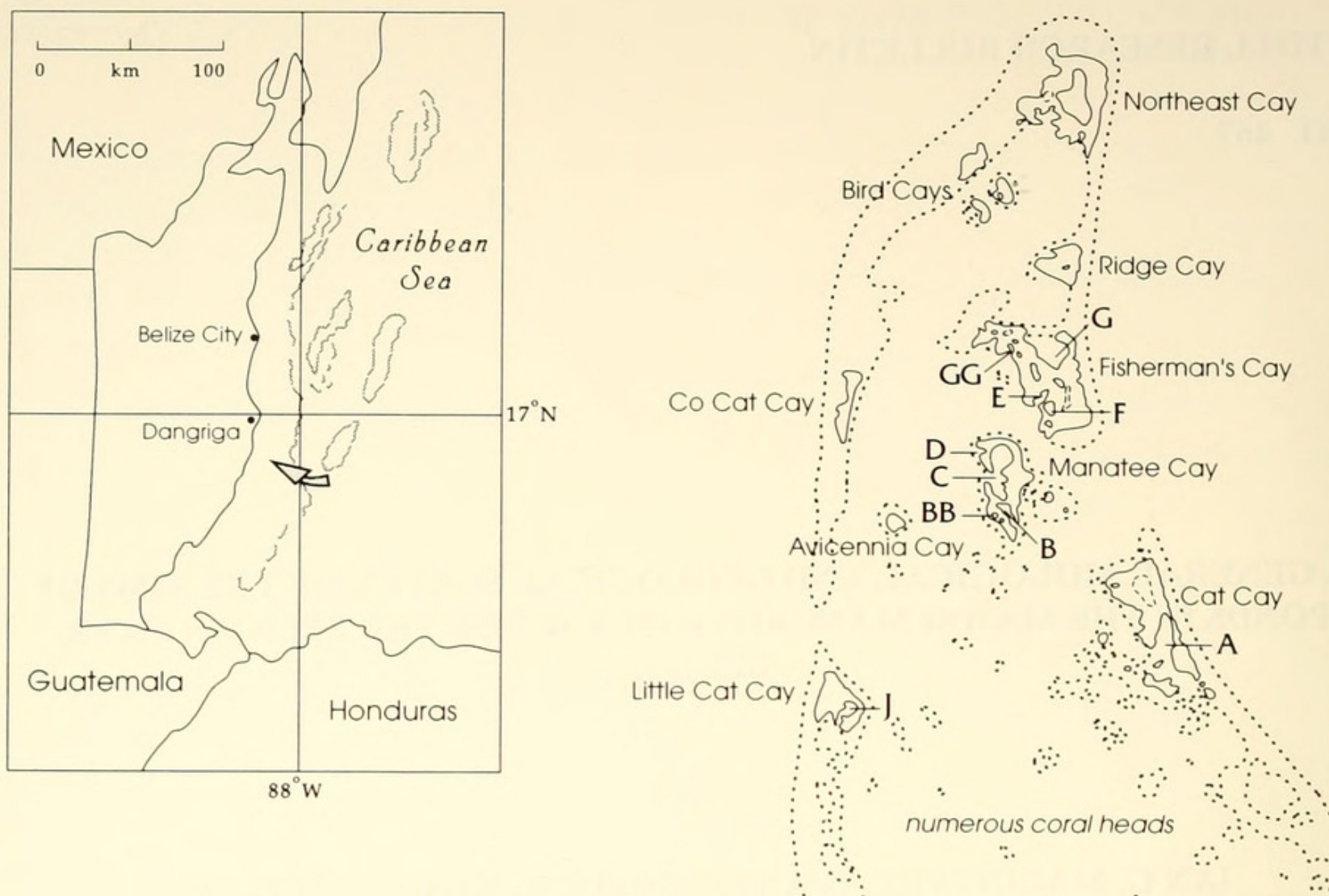

numerous coral heads

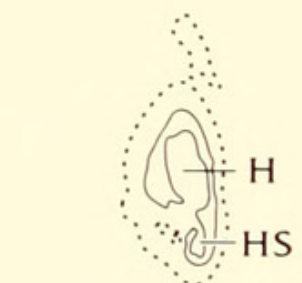

Lagoon Cays
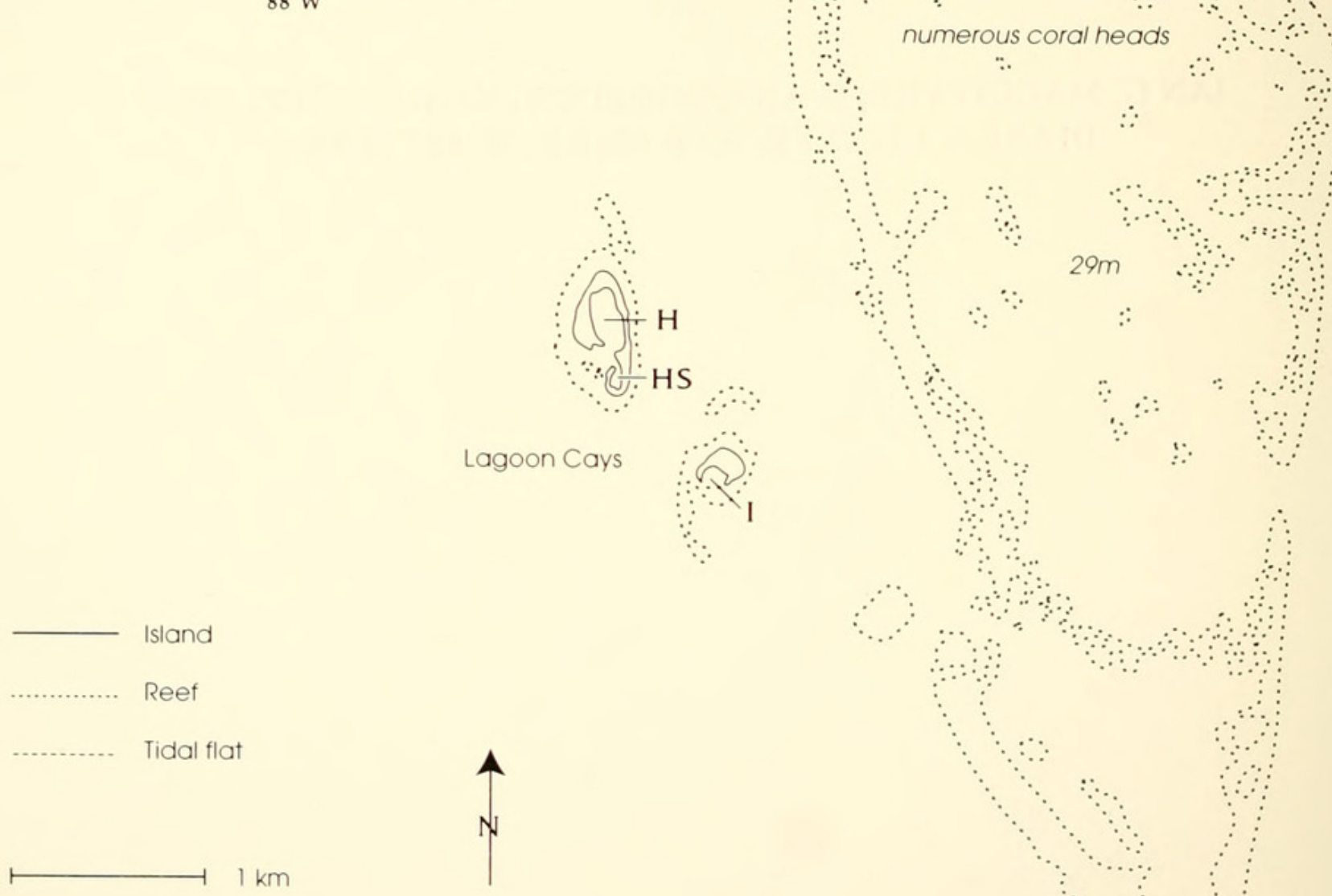

Figure 1. Index map of the Pelican Cays showing the location of the ponds. 


\title{
A GENERAL BIOLOGICAL AND GEOLOGICAL SURVEY OF THE RIMS OF PONDS IN THE MAJOR MANGROVE ISLANDS OF THE PELICAN CAYS, BELIZE
}

\author{
BY \\ IAN G. MACINTYRE, ${ }^{1}$ IVAN GOODBODY, ${ }^{2}$ KLAUS RÜTZLER, ${ }^{3}$ \\ DIANE S. LITTLER, ${ }^{4}$ and MARK M. LITTLER ${ }^{4}$
}

\begin{abstract}
A basic description of the geological and biological characteristics of the rims of major ponds in the Pelican Cays is presented. This report is based on a 1994 general survey that was augmented by observations of benthic community populations and systematic collections completed between 1992 and 1997.
\end{abstract}

\section{INTRODUCTION}

The Pelican Cays $\left(16^{\circ} 39.8^{\prime} \mathrm{N} ; 88^{\circ} 11.5^{\prime} \mathrm{W}\right)$ are a group of mangrove islands (Fig. 1) forming the northwestern section of the Rhomboid Shoals in the southern lagoon of the Belize Brrier Reef complex (Macintyre and Aronson, 1997). These islands occur on elongate shelf atolls with parallel flanks, whose pattern of formation has been controlled by the underlying tectonics of the region (Purdy, 1974a, 1974b). A striking feature of the cays is their distinct circular ponds, which are the result of differential coral and mangrove growth on a Pleistocene subsurface exhibiting a karst polygonal ring pattern (Macintyre et al., this volume). The Pelican Cays ponds constitute pristine, low-energy, benign, and biologically diverse ecosystems dominated by sessile photosynthetic and filter-feeding populations (Littler and Littler, 1997). Most of the marine species are morphologically delicate and vulnerable to damage from the emissions of boat exhausts; physical disturbances by boat wakes, snorkelers, storms, and sedimentation; and natural (Lapointe et al., 1993) and anthropogenic (Littler et al., 1993) eutrophication.

\footnotetext{
'Department of Paleobiology, National Museum of Natural History, Smithsonian Institution, Washington, DC 20560-0125.

${ }^{2}$ Department of Life Sciences, University of the West Indies, P.O. Box 12, Kingston 7, Jamaica.

${ }^{3}$ Department of Invertebrate Zoology, National Museum of Natural History, Smithsonian Institution, Washington, DC 20560-0163.

${ }^{4}$ Department of Botany, National Museum of Natural History, Smithsonian Institution, Washington, DC 20560-0166.
} 


\section{METHODS}

In June 1994, some members of our group conducted a general survey of the geological and biological characteristics of the rims of the Pelican Cays ponds (Fig. 1). Others in the group collected biological information on these ponds at various periods. Maps were drawn from lowaltitude, oblique aerial photographs superimposed on existing nautical charts. Coordinates were confirmed by a hand-held GPS (Garman GP545, 15- to 100-m accuracy), and depth soundings were taken using a hand-held Scubapro PDS-2 dive sonar and were converted from feet to meters.

Between February 1992 and August 1997, samples of pond organisms were systematically collected from mangrove prop roots, seagrass flats, and shallow reefs ridges, as well as from the deeper slopes of seagrass beds and reef ridges. Detailed qualitative observations of populations were made using transect-A methods (Goodbody, this volume; Littler and Littler, 1997, this volume; and Rützler et al., this volume). Voucher specimens were examined live at the Carrie Bow Cay field station; they were then prepared for microscope study, fixed in $10 \%$ formalin-seawater, and preserved in $70 \%$ ethyl alcohol. Sections of the plant materials were made by hand (in the field) or by freezing microtome (in the laboratory). Sections were stained with $1 \%$ aniline blue and mounted using a $20 \%$ glucose syrup (Karo Syrup, Corn Products, Inc.) solution in distilled water containing a trace of phenol. Sponges were sectioned by hand and the sections were dehydrated, cleared, and mounted in Permount (Fisher Scientific Company); preliminary spicule mounts were made after dissolving representative fragments in $5 \%$ sodium hypochlorite. Ascidians were relaxed before fixation by adding menthol crystals to the seawater in observation vessels. The specimens from this study are deposited in the National Museum of Natural History, Smithsonian Institution, Washington, D.C.

In this discussion, the ponds in the Pelican Cays are identified by letters, although some of the ponds have names (Littler and Littler, 1997): Pond A = Cat Cay Bay; Pond B = Cassiopea Cove; Pond $\mathrm{C}=$ Tony's Lagoon; Ponds $\mathrm{E}$ and $\mathrm{F}=$ Frenchy's Ponds; Pond $\mathrm{G}=$ Great Pond; Pond $\mathrm{GG}=\mathrm{B}^{2}$; and Pond $\mathrm{J}=$ Little Cat Bay.

\section{THE SETTING}

The Pelican Cays ponds (Fig. 1) have a number of characteristics in common. Each pond has at least one opening to the surrounding seas, and these openings are restricted to various degrees by coral ridges. Each is surrounded in part by mangrove forests composed of the red mangrove Rhizophora mangle and sporadic stands of the black mangrove Avicennia germinans. These forests have formed an underlying peat substrate, which is usually eroded around the perimeter of the ponds and undercut to expose some of the root system of the forest above; the exposed roots may be referred to as "bank roots," in contrast to the adventitious "hanging roots" that grow down from the canopy into the water below. Bank roots, hanging roots, the bank rim base, and the exposed peat bank provide substrates for sessile organisms and thus support flourishing communities of sponges, ascidians, algae, corals, sabellid polychaetes, molluscs, bryozoans, and other organisms.

Fine organic sediment, derived from the adjacent mangrove forest floor, lies at the base of most pond rims. Observations of the peat margin at ebb tide revealed that a trickle of suspended organic particles often moves across the peat and settles onto the bases of the ponds. These 
bottom sediments are so fine that they are easily disturbed by any movement of the water, as indicated by the random movement of a swim fin. The resulting cloud of suspended material eventually settles on and stresses sessile organisms on the mangrove roots or the peat bank. In many locations the base of the rim is composed of Halimeda sediments or accumulations of bivalve shells, depending on the communities flourishing on the adjacent roots and peat bank. In addition, coral debris is exposed at the base of many undercut sections of the peat banks. This debris derives mainly from the reef facies on top of the Pleistocene karst polygonal ridges, and with the mangroves is responsible for the formation of these ponds (Macintyre et al., this volume).

Where sediment and light conditions permit, turtle grass, Thalassia testudinum, is a common feature on the bottom around the margins of the ponds. In the center of most ponds, the bottom is covered by an organic-rich mud.

\section{THE SURVEY}

Each survey began at the pond openings and continued along the coastal rim in a clockwise direction.

Pond A, Cat Cay (Fig. 2)

The western entrance to Pond $\mathrm{A}$ is closed by a ridge about $5 \mathrm{~m}$ wide across the top; at high tide this ridge crest is only 0.5 to $1.0 \mathrm{~m}$ below the surface. The outer slope, which descends to a depth of about $20 \mathrm{~m}$, is covered in large part by a rich growth of Agaricia tenuifolia (Plate 1c), ${ }^{5}$ whereas the crest is dominated by Porites divaricata and abundant filamentous algae, with small amounts of Thalassia testudinum. Down the outer slope, particularly below 3-5 m, the coral cover is interrupted by large reef-like stands of barrel and rope sponges (Xestospongia muta (Plate 3b), Iotrochota birotulata, and Amphimedon compressa). On the inner side, the ridge slopes down to at least $14 \mathrm{~m}$ in the pond. This inner slope too has rich growths of $A$. tenuifolia, with a few stands of Acropora cervicornis, which in 1994 were partly affected by white-band disease. The Agaricia blades are inhabited by large populations of solitary ascidians (Goodbody, this volume) and sponges, particularly the photosynthetic symbiotic Ulosa funicularis (Plate 3a) (Rützler et al., this volume). The colonies of $A$. tenuifolia are delicately balanced on this slope and are easily disturbed. When swimmers just brush by them, the colonies can become dislodged and roll down a talus slope toward the bottom of the pond. Here and there, the colonies have been stabilized by large clusters of Zoanthus sp. and encrusting sponges (Chondrilla cf. nucula) (Plate 3a), which have grown between adjacent coral colonies, bound them together and, in the case of Chondrilla, overgrown live coral surfaces. These closely packed plates of coral colonies also provide a cryptic environment for colonial ascidians, sponges, and other sessile organisms. The depth at the center of this pond is 11 meters.

'Most of this outer slope population experienced bleaching and subsequently died after long exposure to warm stagnant waters that lasted from August to November, 1998 (Aronson et al.in press). 

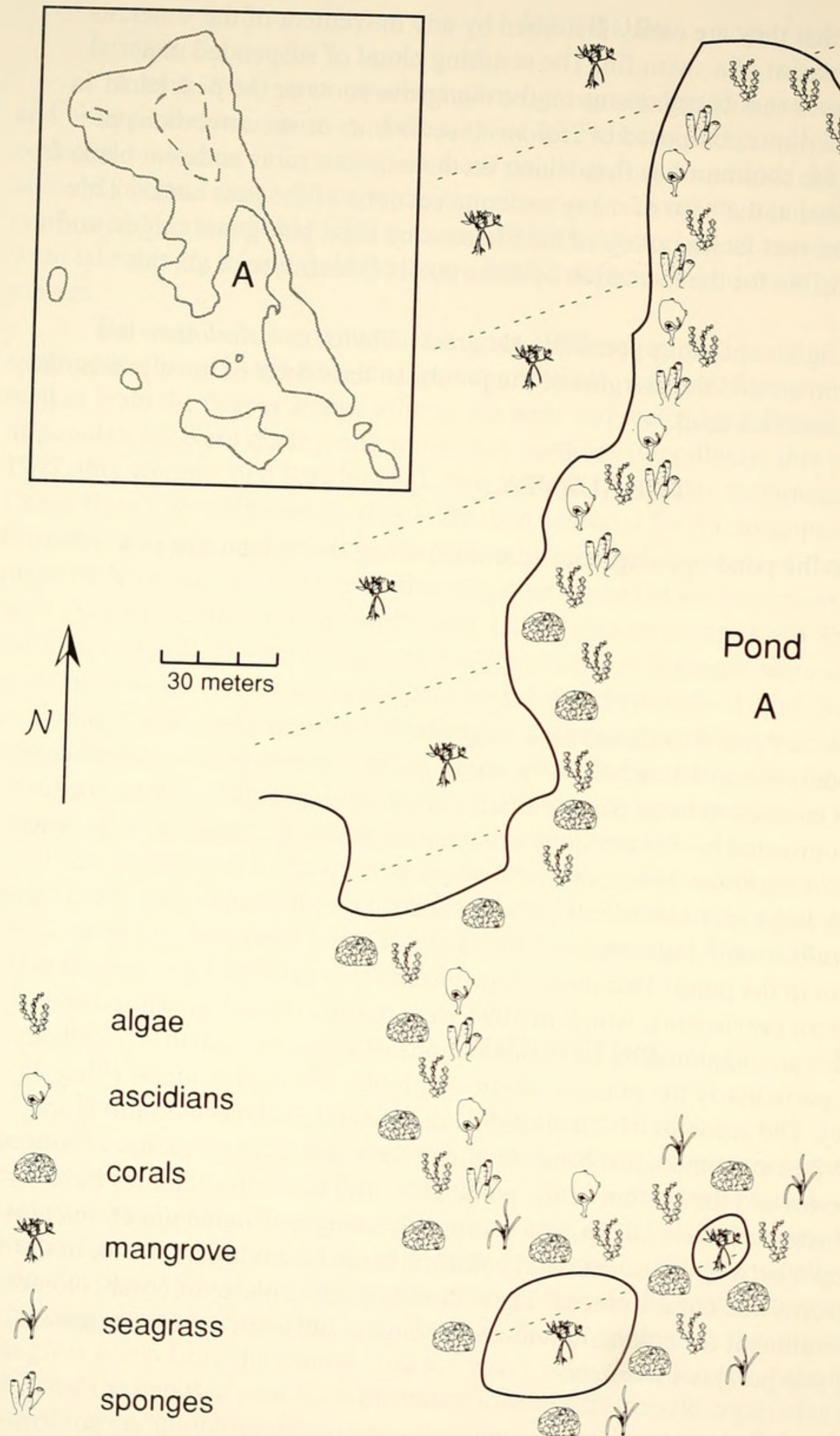

Pond

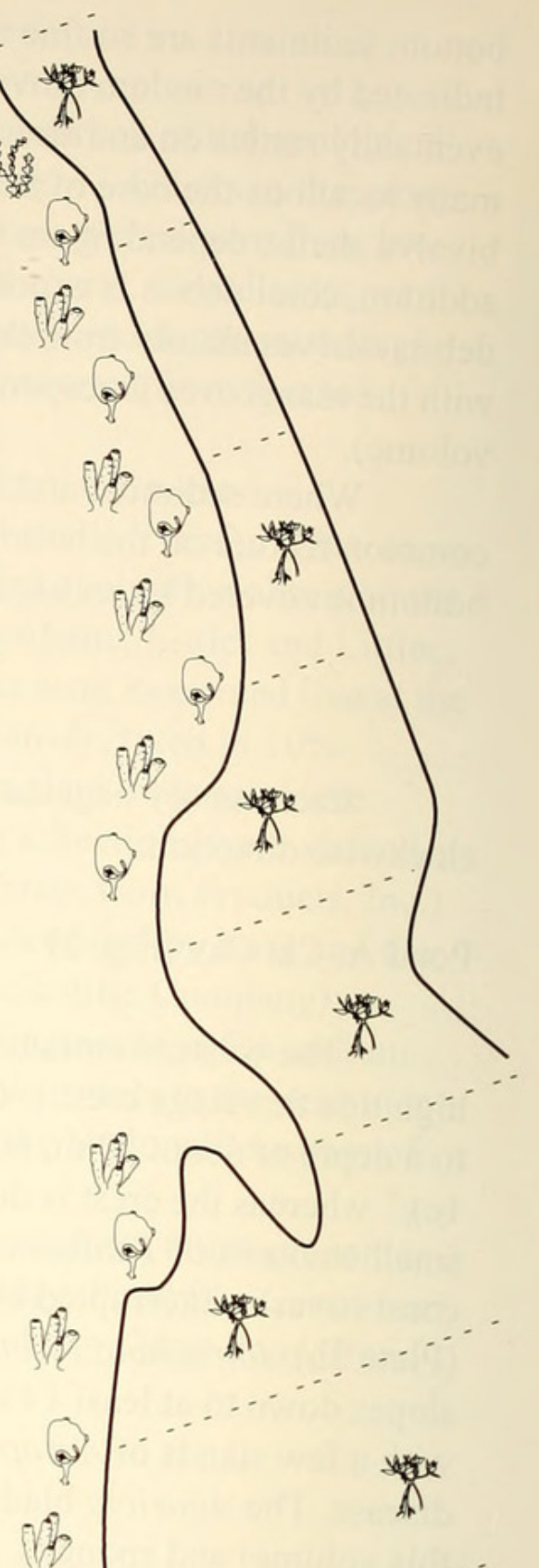

A
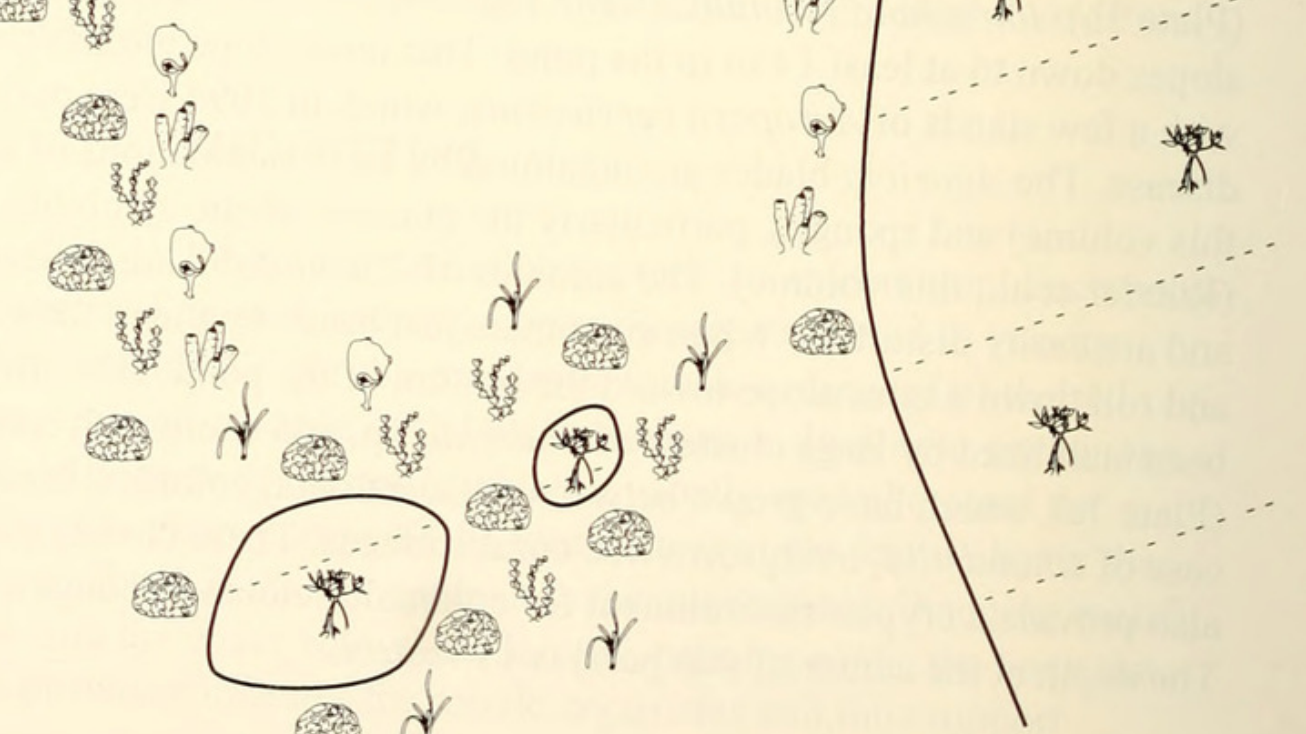
Figure 2. Schematic map showing the distribution of dominant bottom communities around the
rim of Pond A 
Starting from this western entrance and moving around the pond in a clockwise direction, corals (primarily Porites divaricata and Agaricia tenuifolia) and algae dominate the rim, flourishing between and around the mangrove roots for about one-third of the way along the western rim to a point where the mangroves become undercut and expose a coral-rubble base composed mostly of Porites divaricata, Acropora cervicornis, and Millepora sp. With a slight increase in depth, this coral rubble gives way to a muddy Thalassia testudinum bottom. From this point on, bank roots, hanging roots, and exposed peat banks on the western rim have an abundant cover of sponges and ascidians, with some bryozoans and hydrozoans and a few anemones (Lebrunea sp.). The dominant algae are the red Coelothrix irregularis, Acanthophora spicifera, and Spyridia filamentosa; the brown Lobophora variegate, Dictyota spp., and Padina sanctae-crucis; and the green Caulerpa racemosa, C. sertularioides, C. mexicana, C. verticillata, Halimeda opuntia, and Dictyosphaeria cavernosa. Such robust macroalgal populations are indicative of constant, stable, low-nutrient conditions (Lapointe et al., 1993). Unusual species include foliose fleshy red algae (Gracilaria, Meristiella), epiphytic crustose corallines, and the large green sand-dwelling alga Udotea cf. occidentalis.

These sessile communities yielded specimens of the gastropod Calliostoma sp. and the flatworm Pseudoceros crozieri, both of which are probably predators on these communities. On this western rim, one of the most abundant colonial ascidians is Cystodytes dellechialei, of which there are at least five color morphs; these colonies live preferentially on the peat bank. Several species of sponges are also common on the western rim, notably Scopalina ruetzleri (Plate 3e), Desmopsamma anchorata (Plate 3c), Mycale laevis (Plate 3c), Iotrochota birotulata, Haliclona manglaris, and Mycale laxissima. Iotrochota forms dangling ropes of blackish-green sponge hanging from mangrove roots on the lip of the bank. About two-thirds of the way along this western rim there is a distinct mound of dead Acropora cervicornis located a little distance into the pond.

The northern shore is composed of a steep peat bank about $1 \mathrm{~m}$ high, with occasional areas of undercutting. Large populations of the anemones Bartholomea annulata and Aiptasia tagetes occupy the roots and peat bank along this shoreline. Small numbers of the bivalve Chama macerophylla are also found on the roots but not in the quantities seen in Pond C. A luxuriant growth of the alga Lobophora variegata covers this peat bank, and oysters (Crassostrea rhizophorae and Isognomon alatus) are attached to the roots. Both sponges and solitary ascidians are sparse along this north bank, but some species of colonial ascidians, notably Clavelina picta (Plate 2c) and Ecteinascidia turbinata (Plate 2e) are present on hanging roots.

At the center of the northern shoreline the pond is close to the open barrier-reef lagoon on the windward side of the island. The mangroves here are thin, and water flows into the pond across this section of mangrove when wind conditions are strong (the prevailing winds are from the northeast). Simple float tests suggest that this inflow is carried into the center of the western rim of this pond, where some of the richest and most interesting populations of ascidians occur. A small recess, or channel, $42 \mathrm{~m}$ long occurs in the northeast corner of the pond and leads into it from among the mangroves. The bottom sediments in the recess are sulfurous, which suggests poor circulation.

Rich populations of algae, ascidians, and sponges are again abundant on roots and the peat bank along the eastern rim of Pond A, but these filter-feeding communities are not as abundant as on the westward rim. The southern tip of this eastern rim is occupied by a large colony of Montastraea annularis. 
Lying further southeast is a deep channel, and next to it is a thriving coral community surrounding a small mangrove island. Most of this community consists of Agaricia tenuifolia, Porites divaricata, and Millepora sp., with thick growths of Halimeda between these colonies. Scattered colonies of Acropora cervicornis are also present around this island, along with abundant algae and Thalassia testudinum growing between the shallow root system. Notable algae include three markedly different forms of Codium spp. along the southwest margin and large populations of the red alga Hydropuntia cornea on the shallow flats. An Agaricia tenuifolia ridge connects this island westward to a larger mangrove island. Another rich ascidian community flourishes on the mangrove roots of this island. This Agaricia-dominated community continues westward, connecting with the shallow ridge across the pond mouth.

\section{Pond B, Manatee Cay (Fig. 3)}

The entrance to this small pond faces northeast into the direction of the prevailing winds. It is a shallow, muddy pond with a few corals and octocorals at the entrance, which was partly blocked by a shallow flat with two small islands of Rhizophora mangle. The outer, northern margin of these islets has several large populations of the agar-producing red algae Gracilaria cervicornis, G. mammillaris, and Hydropuntia cornea.

The rim of this pond has a curtain of hanging mangrove roots covered by algae and ascidians, including Botrylloides nigrum, Polyclinum constellatum, and Perophora regina; the latter two species have not been recorded in quantity from any other ponds in the Pelican Cays (see Goodbody, this volume). The peat bank around the rim of this pond shows little undercutting, and the bottom is covered with fine sediment, which supports abundant populations of several morphological forms of the large jellyfish Cassiopea xamachana. The brown crown conch Melongena melongena is also common. Ulvalean algae, which indicate eutrophication, are present along the eastern rim. In the southern section, particularly just inside of the entrance, Thalassia testudinum flourishes on the mud bottom, giving way to Syringodium filiforme in the northern part of the pond. Both of these seagrasses have exceptionally long blades $(>1 \mathrm{~m})$.

Pond BB, Manatee Cay

A small, almost circular pond (about $100 \mathrm{~m}$ in diameter) is located southwest of Manatee Cay at $16^{\circ} 39.92^{\prime} \mathrm{N} ; 88^{\circ} 11.54^{\prime} \mathrm{W}$. A narrow entrance measuring about $20 \mathrm{~m}$ across occurs on the western side of the pond. Cutting across the entrance is a ridge with well-developed relief. The crest of this ridge is formed of coral rubble with an abundance of Thalassia testudinum and some Zoanthus sp.; various large anemones are also present, including Stoichactis helianthus and a bright green Actinostella flosculifera partly buried in the sediments. Octocorals, most notably Briareum sp., are scattered across the ridge along with a few solitary ascidians; Polycarpa aurita and Ascidia sydneinsis were recorded during a visit in April 1996. The surrounding sediments contain numerous large burrows, suggesting the presence of stomatopods or calianassids. Just south of the entrance is a spectacular population of the giant paddle-like green alga Avrainvillea asarifolia (with blades measuring $30 \mathrm{~cm}$ by $20 \mathrm{~cm}$ ).

Inside the lagoon, the entire rim is surrounded by a curtain of hanging roots. The pond floor here is about $1.5 \mathrm{~m}$ deep and slopes down to the center of the pond at an angle of about 450 . Much of the peat bank is eroded, exposing a vertical surface about $1 \mathrm{~m}$ high. The bottom of this 
algae

(3) ascidians

corals

octocorals

A mangrove

iv seagrass

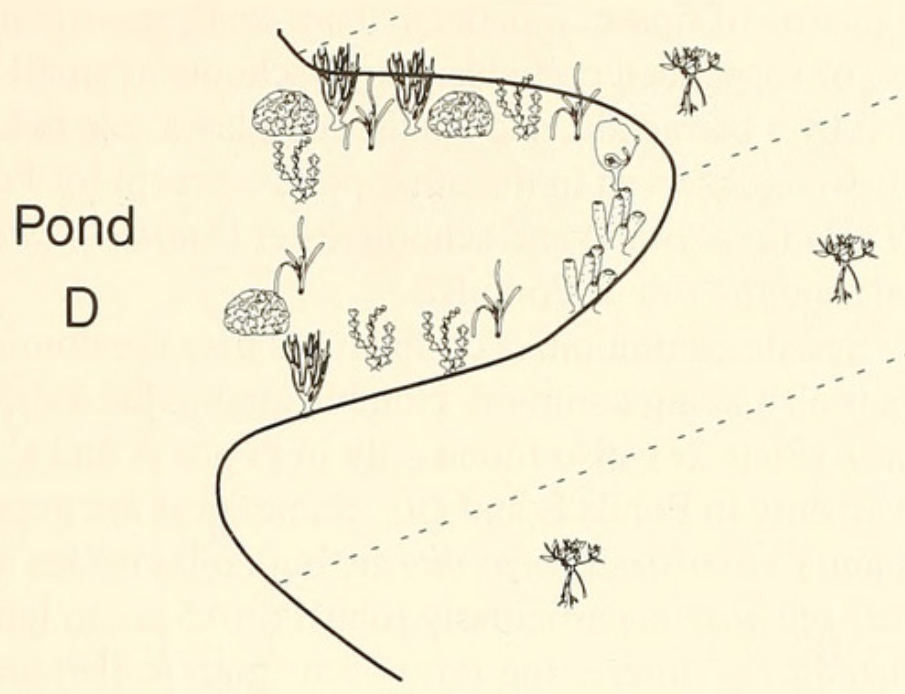

तi sponges

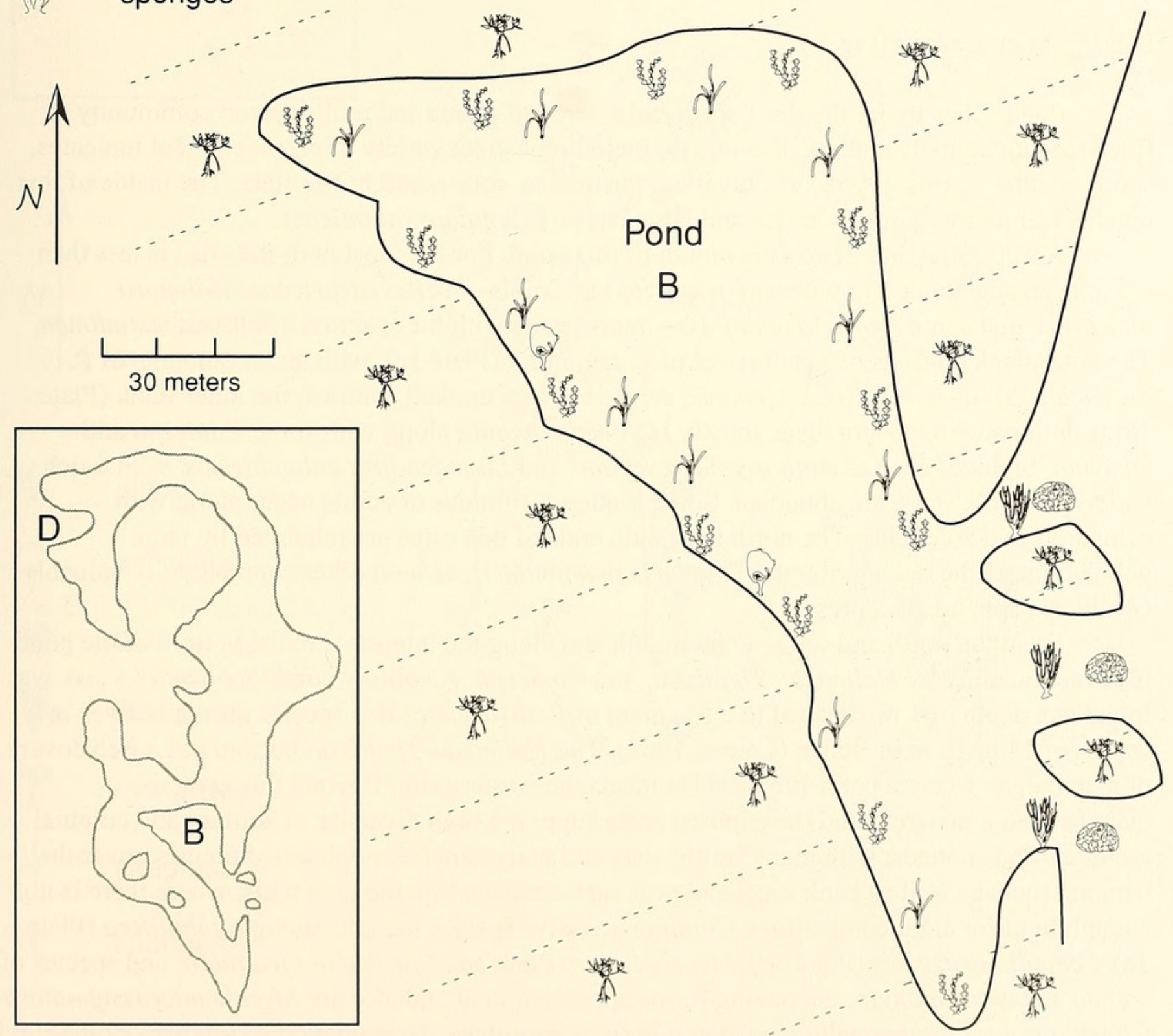

Figure 3. Schematic map showing the distribution of dominant bottom communities around the rims of Pond $\mathrm{B}$ and Pond D. 
pond consists of fine sediments that are easily resuspended, and the water is generally murky because of suspended particles. Large schools of small harengulid fish inhabit the area, each attended by a barracuda, and apparently play a role in keeping sediments in suspension. No such schools were observed in the other ponds, except for Pond I and occasionally Pond A. Numerous grey (Lutjanus griseus) and schoolmaster (Lutjanus adopus) snappers can be seen among the roots around the rim of Pond BB.

Sessile communities on the roots here are dominated by sabellids, with sponges and ascidians also being common. Notable among the ascidians are colonies of Ecteinascidia turbinata (Plate 2e), also found only in Ponds A and C, and Didemnum psammathodes, also observed only in Ponds B and GG. Some roots are populated by clusters of oysters, Isognomon alatus and Crassostrea rhizophorae, but no barnacles are present. The feathery green alga Bryopsis plumose is particularly robust (at $15 \mathrm{~cm}$ in length), while the hanging roots are dominated by an interesting form of the giant-celled green alga Caulerpa nummularia (a new record for the Caribbean).

Pond C, Manatee Cay (Fig. 4)

Pond $\mathrm{C}$ has by far the most spectacular array of plants and multilayered community of filter-feeding animals in the Pelican Cays, including a great variety of algae, colorful tunicates, sponges, tube worms, bryozoans, bivalves, anemones, corals, and brittle stars. The inside of this pond is teeming with juvenile fish and large tarpon (Megalops atlanticus).

A ridge stretches across the mouth of this pond. For the most part, the crest is less than $0.5 \mathrm{~m}$ deep and about $5 \mathrm{~m}$ wide and is covered by corals-Porites divaricata, Millepora alcicornis, and some Agaricia tenuifolia-interspersed with the seagrass Thalassia testudinum. The outer flank consists of a rich cover of $A$. tenuifolia (Plate 1c), with lesser amounts of $P$. divaricata, M. alcicornis, and Acropora cervicornis. In marked contrast, the inner flank (Plate 1d) is dominated by macroalgae, mostly Halimeda opuntia along with some Caulerpa and Dictyota. Sponges such as Anthosigmella varians and Lissodendffyx colombiensis, with a rich variety of brittle stars, are abundant. Some scattered colonies of corals occur along with octocorals and zoanthids. The north and south ends of this ridge are inhabited by large populations of the red agariphyte Gracilaria mammillaris; several other commercially valuable Gracilaria spp. are also present.

From the north end of the pond mouth and along the interior rim, the bottom of the pond is covered mainly by Halimeda, Thalassia, and Caulerpa. A solitary coral, Scolymia lacera, was found at a depth of $1 \mathrm{~m}$ attached to a fragment of $P$. divaricata; this species normally lives in depths of 14 to $40 \mathrm{~m}$ in Belize (Cairns, 1982). The Halimeda-Thalassia bottom has a rich cover of macroalgae where a coral-rubble ridge meets the western rim. Beyond this area, the mangroves are undercut and the exposed roots support a high diversity of solitary and colonial ascidians and sponges, with many brittle stars and platyctenid ctenophores. Sponges cover the hanging roots as well as bank roots and peat surfaces deep into the undercuts, where there is not enough light for algal competitors. Common massive species include Spongia tubulifera (Plate 3d), Scopalina ruetzleri (Plate 3e), Mycale laevis (Plate 3c), Iotrochota birotulata, and species of Ircinia and Xestospongia; encrusting forms appearing in abundance are Mycale microssigmatosa, Clathria venosa, Spirastrella mollis, and Terpios manglaris. Examination of this area of the rim at night revealed an abundance of tentacular structures hanging down into the water; these 

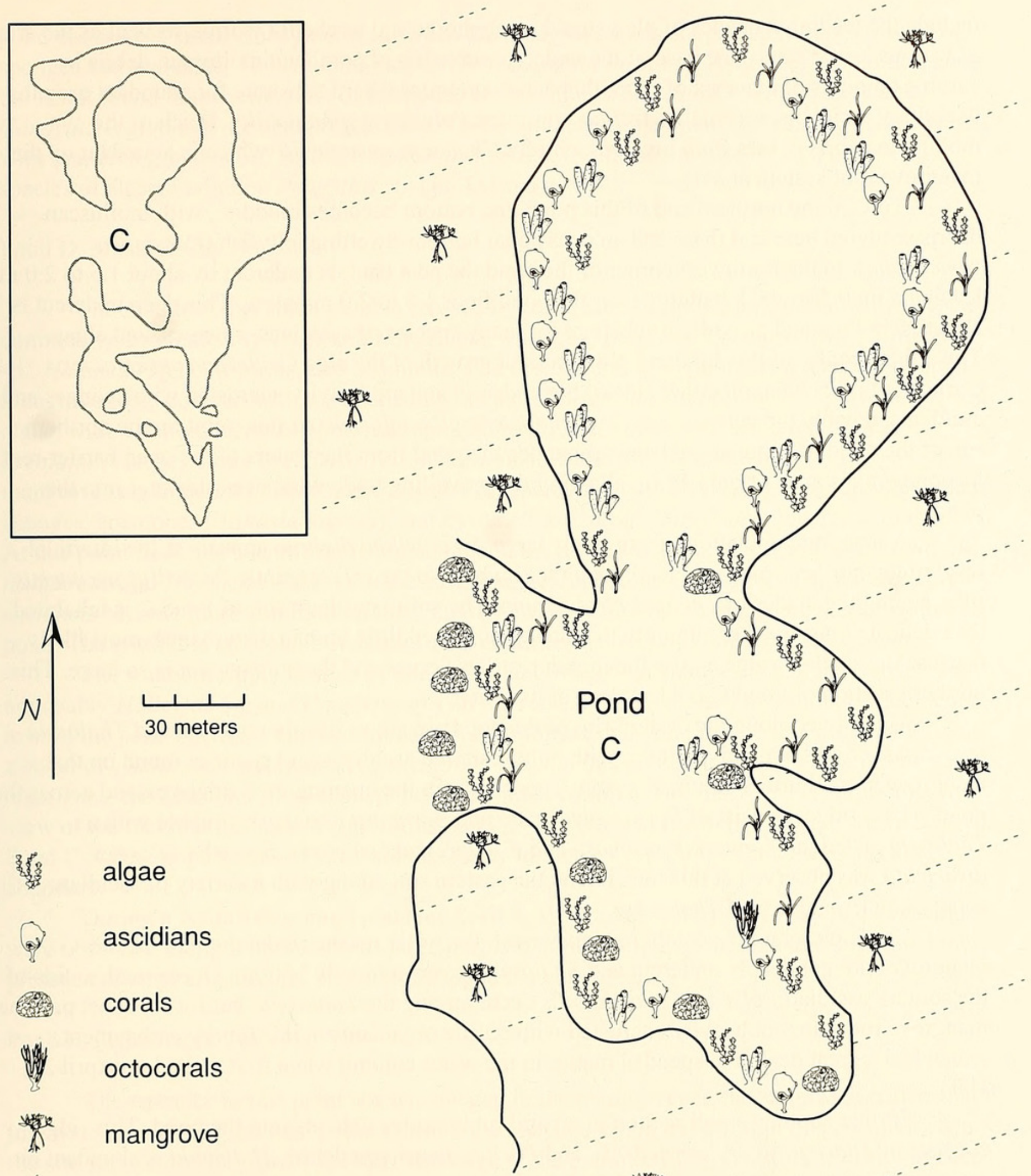

繁 algae

a) ascidians

corals

octocorals

An mangrove

if seagrass

A

1) sponges

Figure 4. Schematic map showing the distribution of dominant bottom communities around the rim of Pond C. 
include the feeding tentacles of platyctenid ctenophores and terebellid worms, as well as the arms of various brittle stars. The base of the undercuts consists of coral and molluscan debris in varying amounts of a matrix of mud; this debris provides a hard substrate for abundant growths of solitary ascidians, especially Ascidia nigra and Polycarpa spongiabilis. Much of the molluscan debris comes from bivalves, chiefly Chama macerophylla, which is abundant on the mangrove root system above.

Toward the northern end of this pond, the bottom becomes muddier, with molluscan debris scattered here and there and an occasional bottom-dwelling jellyfish (Cassiopea xamachana). In the northwest corner of the pond the peat bank is undercut by about 1.5 to $2.0 \mathrm{~m}$, leaving a lip $0.5-\mathrm{m}$ thick hanging over the pond floor 1.5 to $2.0 \mathrm{~m}$ below. This deep undercut is about $20 \mathrm{~m}$ long and provides a substrate for many species of ascidians, sponges, and algae. Toward the center of this lip there is a luxuriant growth of the alga Caulerpa cupressoides. Curtains of roots hang on either side of the undercut and are heavily encrusted with sponges and ascidians, notably the colonial ascidian Diplosoma glandulosum. At this point on the northern rim of the pond, the mangrove fringe separates the pond from the waters of the open barrier-reef lagoon by a distance of only $16 \mathrm{~m}$, allowing the prevailing trade wind to push water into the pond.

A hanging population of extremely large Avrainvillea digitata appears at the intertidal level of the northern margin. Nearby, on the rim base to the east, gigantic Penicillus pyriformis lives among the blades of Thalassia testudinum. The entire northern rim of Pond $\mathrm{C}$ is inhabited by a delicate long-lived community that has experienced little human disturbance, most likely because the shallow ridge across the mouth restricts access and the embayment is so large. This northern section of Pond $\mathrm{C}$ is $11 \mathrm{~m}$ deep at its center.

Mangroves along the eastern rim of the pond are not as deeply undercut and Thalassia testudinum covers a muddy bottom, with only scattered ascidians and sponges found on the mangrove roots. Further south, at a point opposite from the opening, two ridges extend across the pond. These ridges consist of Porites divaricata and Acropora cervicornis rubble with a Thalassia and algal (Caulerpa racemosa and C. cupressoides) cover. Some live Porites divaricata was observed at this location on the eastern rim, along with a variety of ascidians, sponges, macroalgae, and Thalassia.

Continuing into the southern embayment, the water reaches a depth of $14 \mathrm{~m}$; the mangroves are not deeply undercut and Thalassia covers a muddy bottom. Occasional zooids of the solitary ascidian Polycarpa spongiabilis occur among the Thalassia, but for the most part the mangrove roots are not heavily encrusted with sessile organisms in this murky embayment, which had a great deal of suspended matter in the water column when first visited on April 27, 1993.

Further south, a small section of a coral rubble ridge extends into the pond. This ridge consists of Agaricia sp., A. cervicornis, and Porites divaricata debris. Halimeda is abundant on the mangrove roots, among scattered ascidians and gorgonian corals. Extending around the southern rim of the pond, the mangroves are undercut, revealing a peat cover intermixed with coral debris. The mangrove roots support thick growths of Halimeda along with a few colonies of live Agaricia sp. This undercut rim with coral debris at the base and Halimeda between the roots continues right up to the mouth of the pond, with increasing amounts of live coral, including Agaricia sp. and Porites divaricata. In addition, large colonies of the brown encrusting bryozoan Steginoporella magnilabris are present on the mangrove roots. This southern end of the 
pond has several small embayments in which the mangrove roots support luxuriant growths of sponges and ascidians. The colonial ascidian Ecteinascidia turbinata (Plate 2e) is common here but is not found in the remainder of the pond. The anemones Stoichactis helianthus and Condylactis gigantea are also present here. These southern embayments are shallow and covered with scattered growths of Thalassia testudinum resting in fine sediments, as well as several species of algae, including Penicillus sp. and Udotea sp.

Pond D, Manatee Cay (Fig. 3)

The mouth of this small pond is crossed by a sill consisting of coral rubble with a surface community dominated by Thalassia testudinum, Manicina aerolata, Porites porites, Millepora sp., Halimeda sp., octocorals, and zoanthids. The first section of the north rim consists of open mangrove roots covered with the encrusting octocoral Briareum sp.(probably B. polyanthes) and algae, with a bottom cover of Halimeda sp., Thalassia testudinum, and scattered Manicina areolata. A large colony of Siderastrea siderea inhabits the roots. On the north rim, the mangroves are undercut, their roots covered with encrusting octocorals up to a small inlet, where sponges, anemones (Aiptasia tagetes), and oysters (Crassotrea rhizophorae) increase in number. At this point hydroids become more abundant and the muddy bottom is covered with Thalassia testudinum and Halimeda. Further to the east, sponges, anemones, and several species of solitary ascidians become more common on the mangrove roots. Colonial ascidians are absent from this pond. The bottom is an organic-rich mud with continuous cover of Thalassia testudinum.

The southern rim is formed of undercut mangroves with sponges and algae (most noticeably Halimeda sp. and Caulerpa sp.) on the roots, with an increasing number of octocorals toward the pond opening. The bottom consists of mollusc and coral rubble in a mud matrix with a cover of Thalassia testudinum. The mangrove roots in this pond are sparsely covered by sessile organisms, the octocoral Briareum sp. being the most common colonist. This is surprising in view of the fact that the eastern rim of this pond is very close to the richly diverse western rim of Pond C, where populations of Chama macerophylla along with sponges and ascidians are so abundant.

During a visit to this small pond on April 5, 1994, many jellyfish, Cassiopea xamachana, were observed, along with numerous large burrows in the bottom sediments that suggested the presence of large crustaceans, either stomatopods or calianassids.

Pond E, Fisherman's Cay (Fig. 5)

The entrance to this pond is a narrow gap in the mangroves in the southwest corner that is just wide enough to for a boat to pass through; a manatee swam out through this channel when the site was visited on April 19,1994. The ridge at the entrance of this pond is almost $4 \mathrm{~m}$ deep at its center, which is greater than the depths of ridges found in the other ponds. This ridge is dominated by Agaricia tenuifolia, with some Porites divaricata and Acropora cervicornis; sponges and Halimeda are packed between the colonies. At depths of $0.5 \mathrm{~m}$, the southern crest is populated mainly by Agaricia tenuifolia, whereas the shallow northern crest consists of a sandy bottom with Thalassia testudinum and scattered colonies of Manicina areolata, Millepora sp., Montastraea annularis, Porites astreoides, and zoanthids. Octocorals grow around the mangrove roots, along with a light cover of hydroids. The roots here are undercut, and the exposed peat has 
algae

(2) ascidians

corals

octocorals

mangrove

$\downarrow$ seagrass

Wh sponges
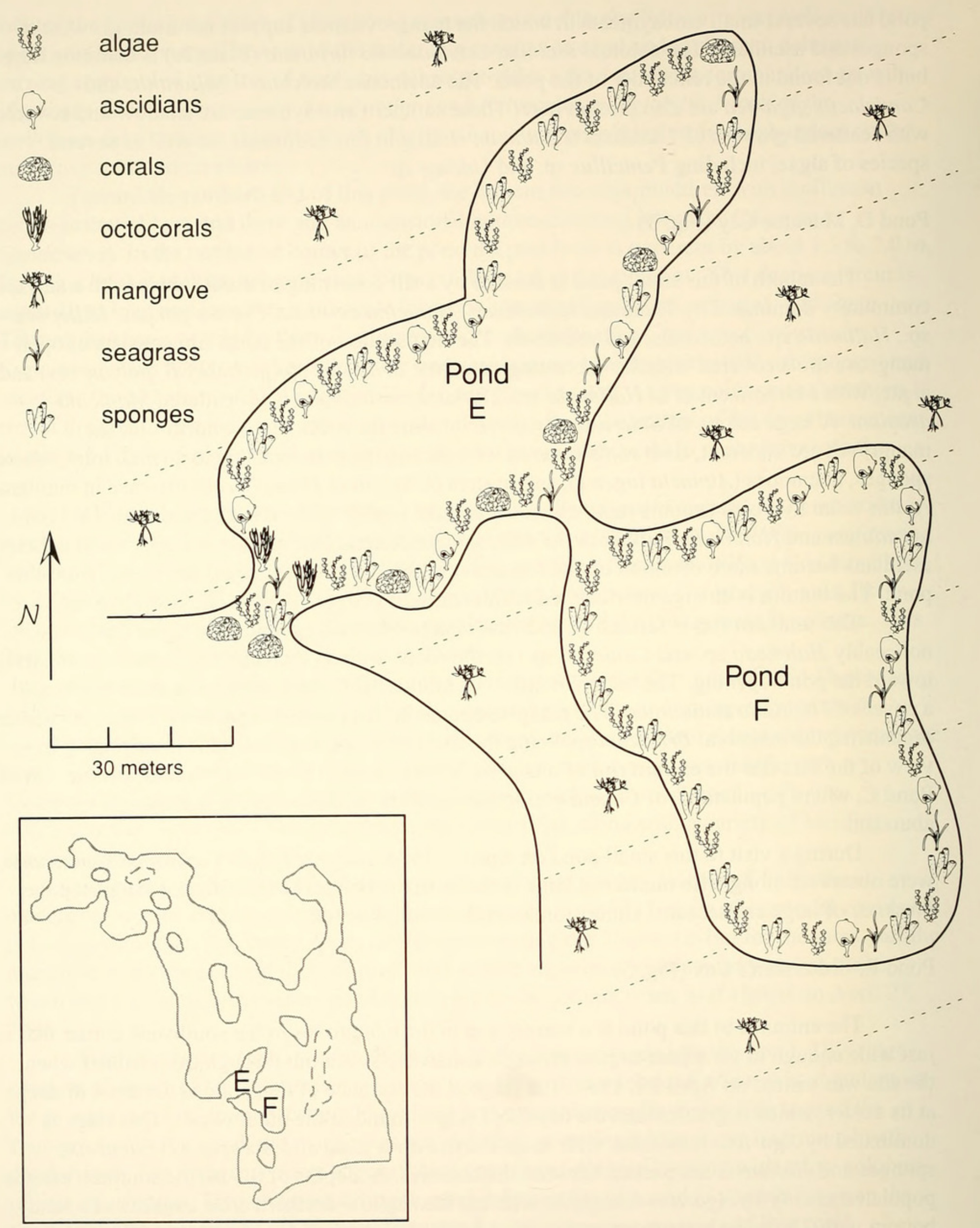
a dense cover of the brown alga Lobophora variegata.

Inside this pond and almost around the entire northwest rim, the peat bank is eroded; the vertical face has a relief of about $1.5 \mathrm{~m}$ and exhibits relatively little undercutting. This bank provides a substrate for many species of ascidians and sponges. Sponges include many large branching clusters of Aplysina fulva and Artemisina melana, massive Scopalina ruetzleri (Plate 3e), Mycale laevis (Plate 3c), and Spongia spp., and encrusting Chondrilla cf. nucula (Plate 3a) and Mycale microsigmatosa. Immediately inside the entrance and extending along the northwestern rim, there is a diverse community of ascidians, especially Clavelina picta (Plate 2c) on hanging roots, with $C$. puertosecensis (Plate 2d) being more common on the peat bank. Dense growths of green algae are also present, notably Caulerpa verticillata on the bank and $C$. racemosa on roots, with Halimeda sp. packed between the root system. The latter contributes a considerable amount of carbonate sand to the pond floor, which is inhabited by several species of solitary ascidians, notably Ascidia interrupta, Polycarpa spongiabilis, and Microcosmus exasperatus (Plate 2f). Approaching the north end of this pond, Halimeda sp. between the roots remains thick, but other algae are also present, including Ventricaria ventricosa. The roots here are covered with numerous sponges, the encrusting bryozoans Trematooecia aviculifer and Stylopoma sp., hydrozoans, and the brown alga Lobophora variegata. A narrow pass at this northern end of Pond E forms a channel into a very small pond. This pass has coral-rubble walls (branching Porites sp.) with a Thalassia testudinum-covered bottom, which supports a large colony of Siderastrea siderea.

The relatively rare ascidian Halocynthia microspinosa was seen on two occasions on the peat bank in this pond. Sabellids, probably a species of Branchiomma, are also common. Bivalves, on the other hand, are not common, but small numbers of Isognomon alatus, Crassostrea rhizophorae, and Chama macerophylla occur on roots, and a single specimen of Modiolus americanus was found in the peat bank on the eastern rim in April 1994. Also at that time, a species of Atrina was common in bottom sediments. Numerous large burrows in the sediments indicate the presence of either stomatopods or callianassids.

The southeast rim has noticeably more hydrozoans and corals than the northwest rim. The mangrove roots opposite the pond opening are encrusted by large populations of ascidians, sponges, and Lobophora sp., while Dictyota sp. and Porites divaricata occur between the roots. The Thalassia/Halimeda muddy bottom contains a considerable amount of branching coral debris. Some colonies of Montastraea annularis appear close the opening into Pond F, but most of them are dead and extensively bored by Cliona sp. sponges. Algal growth becomes very abundant, with Halimeda sp. now found growing on the mangrove roots. A large dead colony of Siderastrea siderea along with some live colonies of Porites divaricata occurs between the roots.

Continuing past the entrance into Pond F, the bottom is covered by Porites divaricata debris along with some live material. The mangrove roots are encrusted with Lobophora variegata, sponges, ascidians, and some octocorals, which become very abundant among the roots near the mouth of this pond. The pond is $11 \mathrm{~m}$ deep at its center.

Pond F, Fisherman's Cay (Fig. 5)

A shallow opening on the southeastern rim of Pond $\mathrm{E}$ forms the entrance to Pond $\mathrm{F}$. The bottom here consists of branching coral that creates a ridge across the entrance. A dead and extensively bored colony of Montastraea annularis is present in this pass, and sponges, 
Millepora alcicornis, and Halimeda sp. are attached to the mangrove roots.

The northern rim is characterized by large quantities of Halimeda opuntia, intermixed with the ascidian Perophora carpenteria. Sponges (Scopalina ruetzleri (Plate 3e), Aplysina fulva) are also common. Continuing on to the eastern rim, one finds a very rich ThalassialHalimeda muddy bottom with patches of Halimeda sand. Sponges, ascidians, Halimeda sp., and some bryozoans flourish on the mangrove roots. All of the mangroves in this pond are undercut.

The southern end of this pond has ascidians, sponges, and Halimeda sp. on the roots and the exposed peat wall is covered with Halimeda sp. and shingle-like growths of the brown alga Lobophora variegata along with a few bryozoans. The bottom consists of a muddy Halimeda sand with abundant branching coral rubble. The southwestern rim is dominated by large curtains of the microscopic red alga Ceramium sp. on both hanging and bank roots. Other noteworthy algal populations consist of draped masses of Halimeda opuntia suspended from mangrove prop roots and mound-like colonies of Avrainvillea asarifolia, often overgrown by creeping strands of Caulerpa spp.

Sponges are particularly abundant on the undercut mangrove roots of the western rim. Oysters, which are common on the roots of Ponds F, are abundant in this southern rim area, along with some Halimeda sp. on the peat banks. Branching coral rubble has accumulated at the base of the undercut and some coral is embedded in the peat. The bottom continues to be a Halimeda sandy mud.

The fauna of this pond is similar to that found on the northwestern rim of Pond E. Scopalina ruetzleri (Plate 3e) is the dominant sponge, and solitary species of ascidian are common, notably Pyura lignosa, Polycarpa spongiabilis, and Ascidia interrupta. Clavelina picta (Plate 2c) and C. puertosecensis (Plate 2d) are common all around the rim, along with small colonies of the ascidians Distaplia corolla and Eudistoma olivaceum. Many species of bivalve molluscs inhabit this pond, including, Chama macerophylla, Brachidontes domingensis, Arca imbricate, Codakia orbicularis, and Spondylus circus. During an April 1994 visit, many specimens of the jellyfish Cassiopeia xamachana were observed on the bottom of this pond.

Pond G, Fisherman's Cay

This is a large horseshoe-shaped bay at the northern end of Fisherman's Cay. It has a wide opening facing north, which is crossed by a shallow coral rubble ridge with an abundance of Thalassia testudinum containing zooids of the ascidians Polycarpa spongiabilis and Herdmania momus and scattered coral heads. Islets of Rhizophora mangle are established along the western edge of this ridge. Noteworthy features are abundant standing crops of commercial agariphytes, such as Gracilaria cervicornis, G. mammillaris, Meristiella gelidium, and M. echinocarpum, along the northwestern (outer) border of the lagoon among isolated colonies of the fire coral Millepora complanata. Ulva rigida blades are prevalent on nearby islet roots directly beneath a seabird roosting site. Moving clockwise around this pond, immediately inside the entrance in the northeast corner is an eroded peat bank about 1.5 to $2.0 \mathrm{~m}$ high with no undercutting. The mangrove fringe at this point is narrow, so the waters of the open barrier-reef lagoon have easy access to the pond. Bank roots are exposed on the peat inside this pond, and there is only a thin fringe of hanging mangrove roots, populated mainly by ascidians and some sponges. These ascidian populations do not exhibit the species richness seen in many other ponds, notably Pond 
A and Pond C. Other common components of the sessile community on roots are the bivalves Chama macerophylla, Crassostrea rhizophorae, and Ivognomon alatus; the anemones Aiptasia tagetes, Bartholomea annulata, and Stoichactis helianthus; and the barnacle Balanus eburneus.

The eroded peat bank continues around the rim of this pond, but as it approaches the southeastern rim it loses its vertical relief and eventually slopes down at a shallow angle into the pond and becomes heavily pitted. At this point sponges increase in number while the solitary ascidians decrease. Thalassia testudinum grows on the bottom around almost the entire rim of the pond, and there are occasional patches of Halimeda sp. and other algae. These plants grow on a narrow sediment bottom that slopes steeply toward the center of the pond to a depth of 10 to 12 $\mathrm{m}$. Numerous colonies of the rare ascidian Pycnoclavella belizeana inhabit the southern rim. The spongy green alga Avrainvillea nigricans forms a sparse aggregation on the shallow peat bank at the southern margin, which is the habitat of gigantic specimens of fan-like Udotea $\mathrm{cf}$. occidentalis extending in a $10 \mathrm{~m}$-long by $1.0 \mathrm{~m}$-wide strip along the rim base. Further back among the shallow roots is an extensive patch of $A$. digitata. Sessile individuals of Cassiopea xamachana are common, and several individuals of the unusual brown crown conch Melongena melongena are also present. The predominant macroalgae on the roots are Acanthophora spicifera and various forms of Caulerpa racemosa. The creeping alga Coelothrix irregularis forms dramatic neon-blue colonies on submerged fallen trees. The benthic community just beneath the mangrove roots rests on a bivalve-Halimeda-hash substrate dominated by rhizophytic plants (Thalassia testudinum and Caulerpa racemosa covered by large mats of Ceramium sp., Caulerpa mexicana, and Caulerpa sertularioides). Dominant on the peat bank among shallow prop roots are the brown alga Padina gymnospora and the filamentous green Caulerpa verticillata.

Continued circumnagivation of the pond rim in the northwest corner leads to islets of Rhizophora mangle established at the western end of the ridge crossing the mouth of the pond. Noteworthy features here are abundant standing crops of commercial agariphytes such as Gracilaria cervicornis, G. mammillaris, Meristiella gelidium, and M. echinocarpum, along the northwestern (outer border) of the lagoon among isolated colonies of the fire coral Millepora complanata. Ulva rigida blades are prevalent on a nearby islet on roots directly beneath a seabird roosting site.

Ponds GG, Fisherman's Cay

This three-pond complex on the western side of Fisherman's Cay, appears to have experienced considerable degradation since earlier observations (1992-93), primarily as a result of sedimentation (stress) and boat damage (physical disturbance) (Littler and Litter, 1997). However, colorful sponges and macroalgae are still prevalent on the mangrove prop roots of both ponds. The western margin is healthy and contains a mangrove root community dominated by gorgonians, anemones, stony corals, and macroalgae such as the shelf-former Lobophora variegata. Adjacent is a seagrass bed with numerous Bryopsidales, red and green colored species of Laurencia, Coelothrix irregularis, and Ceramium sp., grading into an Agaricia tenuifolia ribbon reef containing an individual barrel sponge Xestospongia muta (Plate $3 \mathrm{~b}$ ) that is $>1 \mathrm{~m}$ high. The bed drops sharply to a depth of $24 \mathrm{~m}$. 
This is a large pond with a central depth of 15 to $20 \mathrm{~m}$. Its broad entrance lies on the south side, just behind a ridge of coral rubble, octocorals, and Thalassia testudinum. An eroded peat bank 1.5 to $2.0 \mathrm{~m}$ high runs around the entire rim and is only slightly undercut except for areas of the western rim, where it is undercut as much as $2.0 \mathrm{~m}$. Present along most of the rim is a narrow curtain of hanging mangrove roots, and the base has extensive beds of Thalassia testudinum.

One of the most striking features of this pond is the abundance of solitary ascidians on roots and on the bank, notably Ascidia nigra, A. interrupts, and Microcosmus exasperatus (Plate $2 \mathrm{f}$ ). With the exception of Distaplia corolla, colonial ascidians were not at all common. The brightly colored species of Clavelina, which were so abundant in other ponds, especially Ponds $\mathrm{A}$ and $\mathrm{C}$, were not found. Sponges are also sparse, particularly vigorously growing forms such as Scopalina ruetzleri, which were also common in other ponds. On the other hand, this is one of the few ponds inhabited by large populations of the barnacle Balanus eburneus, which are common along some sections of the rim. Bivalves are also appear on roots and on the peat bank, especially Chama macerophylla, Crassostrea rhizophorae, Ostreaftons, and Isognomon alatus. Broken fragments of bivalve shells attest to the presence of an unidentified predator on these communities. The tests of some ascidians such as Ascidia nigra and Pyura lignosa, were found sliced open, probably a result of trunkfish attacks (Lactophrys sp.). As in other lagoons, juvenile parrotfish are abundant grazers along the root and bank rims.

Occasional clusters of the anemones Aiptasia tagetes and Bartholomea annulata occur on the upper surface of the peat bank. Ophiurids are also common on the bank and roots around the rim of this pond. The southeast corner has a deep but narrow side channel. The fauna in this channel appears more diverse than in the main pond and includes a number of the colonial ascidians on roots recorded elsewhere in this pond. Sponges are also abundant in this channel, in contrast to the main pond, where they are scarce. The fact that this small side channel is fairly sheltered may account for the abundance of colonial ascidians and sponges.

\section{Pond I, South Lagoon Cay}

This is not so much a pond but a large embayment on the south side of the cay. When visited in April 1993, the bay appeared eutrophic green in color, and it contained large schools of small harengulid fish; the food chain is probably supported by a colony of pelicans nesting in trees in the southeast comer of the bay, which deposits a large supply of fecal material into the water. The roots around this bay have large quantities of the alga Caulerpa sertularioides, an abundance of sabellid worms, many barnacles (Balanus eburneus), and the bryozoan Schizoporella sp. The ascidian fauna is typical of fairly eutrophic conditions and includes Polyclinum constellatum, Symplegma brakenhielmi, Ecteinasciditi styeloides, and Lissoclinum fragile. Ascidia nigra and Ecteinascidia turbinata (Plate 2e), both normally expected to occur in such high-nutrient conditions, are not present.

\section{Pond J, Little Cat Cay}

The entrance to this pond lies on the southern side of Little Cat Cay and sits behind a 
shallow coral rubble ridge containing prominent growths of Thalassia testudinum along with large growth forms of Udotea cf. occidentalis. The pond is small, approximately $175 \mathrm{~m}$ long, about $100 \mathrm{~m}$ across, and not more than $6 \mathrm{~m}$ deep; coordinates for this pond are $160^{\circ} 39.13^{\prime} \mathrm{N}$; $88^{\circ} 11.96^{\prime} \mathrm{W}$. The pond is entirely surrounded by mangrove forest, and the peat banks are extensively undercut in places, especially along the northeastern rim. This undercutting has exposed a system of bank roots, which are shielded around most of the pond by a fringe of hanging roots; shell and coral debris line the pond floor beneath the undercut. As in other ponds, these roots are covered by extensive growths of sessile organisms, especially the solitary ascidians Pyura lignosa, Polycarpa aurita, Ascidia interrupts, Polycarpa spongiabilis, and Microcosmus exasperatus (Plate 3f), as well as many colonial ascidians, including Botrylloides nigrum, Symplegma brakenhielmi, Lissoclinum fragile, Diplosoma glandulosum, and Perophora carpenteria. Other common inhabitants of the sessile communities are sponges, small anemones, sabellid worms, and the oyster Isognomon alatus. The alga Caulerpa racemosa is common on some roots along the western shore of this pond.

\section{Characteristic Communities around Some Cays}

Cat Cay South Island (see Littler and Littler, 1997), a small mangrove island just below the mouth of Cat Cay Bay, contains three markedly different growth forms of Codium spp. along the southwest margin. Cat Cay South Island is bordered by a narrow grass flat (Thalassia testudinum), except for regular intervals of "ribbon reefs" of the leaf coral Agaricia tenuifolia, which forms crescents connected at their proximal ends to the mangrove stands. Here the trees and seagrass flats extend as points into the ribbon reefs. Several of these extended flats support large populations of the red alga Hydropuntia cornea (which is locally valued as an aphrodisiac when prepared in porridge and is commercially bottled as "Double Trouble Sea Moss" in the Lesser Antilles). These mangrove root systems also contain unusually extensive colonies of stony corals along with abundant macroalgae, sponges, tunicates, and anemones.

Avicennia Cay, a small mangrove island resting on an isolated lagoonal patch reef just to the southwest of Manatee Cay, was surveyed from the reef slope upward to the edge of the mangrove prop roots. The steep outer slope was found to be covered by Agaricia tenuifolia leveling off in the shallows to form a gorgonian/seagrass community. A passing manatee was observed in this habitat during May 1995. The north side of the cay is the site of a shallow reef crest formed mainly by the fire coral Millepora complanata and the finger coral Porites porites.

Behind this crest, shallow seagrass beds adjoin the mangrove treeline. Agariphytes (Gracilaria cervicornis, G. mammillaris, and Hydropuntia cornea) are abundant on the seagrass and mangrove root systems here. The slight embayment on the south end of the cay is sandy and slopes upward to dense stands of Thalassia testudinum; the mangrove root systems are not particularly rich, and their algal populations are similar to those on the west side of Steward Cay to the north.

Ridge Cay is surrounded by seagrass beds and is the only site containing the economically important carrageenan producer Eucheuma isiforme (also used to make a sea-moss beverage). The eastern-facing (outer) bedded mangrove prop roots are covered with interesting and colorful populations of small epiphytic clumps of seaweeds such as the grape-like Botryocladia spinulifera, mesh-like Anadyomene stellata, feathery Bryopsis plumosa, Laurencia spp., Codium spp., and encrusting Peyssonnelia boergesenii. Some lagoonward hanging roots 
support unusually large populations of various Caulerpa species and calcareous Halimeda opuntia.

Northeast Cay, the northernmost island, contains a substantial fish camp at the western tip and serves as a popular anchorage for sailboats. The small coves southeast of the fish camp contain a community similar to the GG ponds of Fisherman's Cay, but populations are small, and the area is overgrown by curtain-like masses of a colonial Ceramium diatom. The mangrove prop roots outside the coves are richer but red-algae are predominant (Laurencia papillose, Digenia simplex, Acanthophora spicifera). Unattended fish traps inside the small coves during May 1995 contained dead and dying French angel fish and gray snapper. The northern margin of this island is especially rich in gorgonian corals (fan and branched forms) and elkhorn coral (Acropora palmata) patch reefs, with another developing fish camp conspicuous along the shoreline.

The Bird Cays consist of three islands, the westernmost of which has an algal community similar to that of Co Cat Cay and Little Cat Cay to the south (described below). The northeastern and southeastern Bird Cays are located in the atoll-like lagoon and are surrounded by narrow seagrass flats that drop from an Agaricia margin to steep sediment-strewn slopes. Both of these islands contain bird roosting sites; ulvalean green algae associated with eutrophication are present but minimal. Populations at Co Cat Cay and Little Cat Cay, the two westernmost cays in the Pelican Cays group, are not particularly noteworthy except for their algal floras, which resemble those of the western cays of Blue Ground Range and Stewart Cay to the north. The eastern borders of each are composed of narrow strips of seagrass beds (Thalassia testudinum) that slope steeply into the lagoon with scattered heads of the branched fire coral Millepora complanata and the massive starlet coral Siderastrea siderea at the upper margins. The mangrove-root epiphytes are heavily laden with sediment and consist of various Galaxaura spp., Acanthophora spicifera, and Lobophora variegata. The western borders are richer and more interesting, with broad shallow seagrass flats containing large fan and whip gorgonians, Millepora complanata, Montastraea annularis, and Porites heads. The roots are rich in Anadyomene stellata, Lobophora variegata, Gracilaria mammillaris, Bryopsis plumose, and many Caulerpa spp., along with anemones and corals. The southern portion outside the entrance to Pond $\mathrm{J}$ is especially rich in seaweeds such as Codium sp. and Hydropuntia sp. of impressive size.

The mangrove prop roots on the western tip of Little Cat Cay are heavily epiphytized by the weedy red alga Acanthophora spicifera. The outer (eastern) margin of the reef at the southeast tip of Cat Cay, just at the start of Five Mile Flat (see Littler and Littler, 1997) where it adjoins the island, was surveyed down to depths of $30 \mathrm{~m}$. Below a depth of $26 \mathrm{~m}$, the plan sandy bottom levels off and gradually slopes to deeper depths. From depths of 20 to $26 \mathrm{~m}$, the bottom consists of sand-inundated rubble with sparse biota. From depths of 20 to $8 \mathrm{~m}$, Halimeda spp. and Lobophora variegata are abundant. From depths of $8 \mathrm{~m}$ and upward, sponges, bryozoans, and the green macroalgae Penicillus pyriformis, Halimeda spp., Udotea spp., and the brown $L$. variegata are predominant among the Agaricia tenuifolia that flourishes between 3 and $15 \mathrm{~m}$. Many calcareous algae such as Peyssonnelia boergesenii, Jania adherence, crustose Corallinaceae, and Amphiroa spp. are present on the dead skeletons of A. tenuifolia. In depths of less than $7 \mathrm{~m}$, the seagrass Thalassia testudinum, large gorgonians (whips and fans), and corals such as Porites porites, P. astreoides, and Millepora complanata are prominent. 


\section{DISCUSSION}

The preceding observations are of a general qualitative nature owing to the lack of good quantitative data on most of the communities. Furthermore, many organisms were difficult to identify accurately in the field. Nevertheless, the survey yielded sufficient information demonstrating that the Pelican Cays ponds are of considerable interest and can contribute greatly to scientific understanding of Caribbean marine sessile communities. A challenge for future studies will be to explain the differences and similarities between the various ponds. For example, the western rim of Pond $\mathrm{A}$ is similar in many respects to the northwestern part of Pond $\mathrm{C}$, but both differ markedly from the western and northern rims of Pond $\mathrm{H}$. All three of these ponds are large and are oriented in a north-south direction, so they remain sheltered from the prevailing northeast trade winds. All three ponds, however, show some sign of water replacement at the northern end across the mangrove rim when the tide is high and the trade winds are blowing strongly. Whether this water flow pattern influences the types of communities in the ponds is at present unclear.

Several of the ponds exhibited high levels of species diversity, notably Ponds A, C, and $\mathrm{E}$; this may be associated with the proximity of coral reef communities at the pond entrance. Some other ponds have unique features: Pond D, for example, is populated by octocorals that do not grow to any extent in the other ponds; Pond B has populations of Perophora regina, an ascidian otherwise recorded only from Twin Cays and Blue Ground Range further north on the barrier reef platform. Pond BB, which is very close to Pond B and separated from it by only a narrow area of mangrove swamp, lacks Perophora regina but has an abundance of another perophorid, Ecteinascidia turbinata, otherwise abundant in only in Pond C. Balanus eburneus, a large barnacle widely distributed in Caribbean mangrove communities, is only sparsely distributed in the ponds of the Pelican Cays. It occurs in Ponds C, G, H, and L, but not in Ponds $\mathrm{A}$ or E. Sponge diversity in the better-studied ponds A, C, E, and F is different in species spectrum from all others mangrove species studied in the Belize lagoon and approaches that of open reefs, although the species composition only partly overlaps that of known reef environments. About $40 \%$ of sponge species collected in the Pelican Cays ponds are unusual, aberrant, or undescribed.

In summary, the Pelican Cays represent a spectacular, high-biodiversity, low-energy environment dominated by photosynthetic and filter-feeding populations. Most are physically delicate and highly susceptible to damage from boat wakes, careless swimmers, physical contact (e.g., trampling), sedimentation, and nutrient enrichment. The existence of such high biodiversity in a small geographic area can be attributed to the unique juxtaposition of mangrove, coral, seagrass, and algal biomes under stable oligotrophic conditions (as indicated by the consistently "gin-clear" waters). Few of the ephemeral sheetlike and filamentous green algae indicative of eutrophic bird islands (e.g., Man-of war Cay, Douglas Cay) or anthropogenically polluted systems (see Littler and Littler, 1997) are present. A long-term study of the trophic structure of the Pelican Cays ponds could shed some light on the factors controlling the distribution of organisms within them. 


\section{ACKNOWLEDGMENTS}

Special recognition is due to Paul Shave of Wee Wee Cay who first introduced us to the Pelican Cays by showing us Pond A in 1992. That visit marked the beginning of our studies in this area. Tony Rath brought to our attention Pond $\mathrm{C}$ and provided some excellent aerial photographs of the ponds. Very special thanks to Victoria E. Macintyre Saville, Michael R. Carpenter, and Bruno Pernet for field assistance. We are also grateful to William T. Boykins and Molly K. Ryan for valuable help with graphics and design; Barrett L. Brooks for support during botanical work; and Charlotte Goodbody for assistance in the preparation of this manuscript. Funding for the botanical research was provided by NSF Grant DEB-9400534, Harbor Branch Oceanographic Institution, and the Smithsonian Marine Station, Fort Pierce, Florida. Fieldwork for this survey was supported by the National Museum of Natural History's Caribbean Coral Reef Ecosystem Program (CCRE Contribution No. 577).

\section{REFERENCES}

Aronson, R. B., W. F. Precht, I. G. Macintyre, and T. J. T. Murdoch

2000 Coral Bleach-Out in Belize. Nature (in press).

Cairns, S. D.

1982. Stony corals (Cnidaria: Hydrozoa, Scleractinia) of Carrie bow Cay, Belize. In The Atlantic Barrier Reef Ecosystem at Carrie Bow Cay, Belize, edited by K. Rützler and I. G. Macintyre, 271-302. Smithsonian Contributions to the Marine Sciences, No. 12. Washington, D.C.: Smithsonian Institution Press.

Lapointe, B. C., M. M. Littler, and D. S. Littler

1993. Modification of benthic community structure by natural eutrophication: The Belize Barrier Reef. Proceedings of the 7th International Coral Reef Symposium, Guam, v. 1, pp. 323-334.

Littler, D. S., and M. M. Littler

1997. An illustrated marine flora of the Pelican Cays, Belize. Bulletin of the Biological Society of Washington 9:1-149.

Littler, M. M., D. S. Littler, and B. E. Lapointe

1993. Modification of tropical reef community structure due to cultural eutrophication: The southwest coast of Martinique. Proceedings of the 7th International Coral Reef Symposium, Guam, v. 1, pp. 335-343.

Macintyre, I. G., and R. B. Aronson

1997. Field guide to the reefs of Belize. Proceedings of the 8th International Coral Reef Symposium, Panama, v. 1, pp. 203-222.

Purdy, E. G.

1974a. Reef configuration: Cause and effect. Society of Economic paleontologists and Mineralogists, Special Publication, No. 18, pp. 9-76.

1974b. Karst-determined facies patterns in British Honduras: Holocene carbonate sedimentation model. American Association of Petroleum Geologists 58:825-855. 


\section{APPENDIX}

\section{STATUS OF SCLERACTINIAN CORALS IN SOME PELICAN CAYS PONDS FOLLOWING THE 1998 BLEACHING EVENT}

BY

\section{IAN G. MACINTYRE}

On June 11, 13, and 15, 1999, I visited Pelican Cays ponds A, C, D, and E to assess the status of the scleractinian corals following the massive 1998 bleaching and die-off of corals in the surrounding rhomboid shoals (Aronson et al., 2000). Unusually high water temperatures recorded on the shallow reefs during this bleaching killed almost all the agariciid corals in the shoals and the few Acropora cervicornis that had survived an earlier outbreak of white-band disease (Aronson and Precht, 1998).

\section{Pond A, Cat Cay}

All the Agaricia tenuifolia colonies that previously formed a rich cover on both flanks of the ridge across the western entrance of this pond are now dead, as are the associated Acropora cervicornis, Millepora alcicornis, and most of the Porites divaricata. Much of this recently dead coral is already extensively covered by the encrusting sponge Chondrilla cf. nucula, mats of Zoanthus sp., and macroscopic algae, primarily Halimeda opuntia (Figs. 1,2). Only traces of live Porites divaricata, Colpophyllia natans, and Porites astreoides were found on the crest of this ridge (Fig. 3a,b).

No live corals were found along the western rim north of this entrance. The once lush growths of Agaricia tenuifolia and Porites divaricata around the red mangrove stilt roots are dead and overgrown by sponges, zoanthids, and macro-algae (Fig. 4).

The other coral area in Pond A occurs at the southern end, where coral communities once formed a rich cover around the small mangrove island and along the ridge connecting this island to the western entrance ridge. All Agaricia tenuifolia, Porites divaricata, Millepora sp., and Acropora cervicornis reported in our original survey are dead and covered with an expansive growth of sponges and macro-algae such as Halimeda opuntia and Caulerpa racemosa and clumps of blue-green algal filaments (Fig. 5).

Pond C, Manatee Cay

Here, too, the spectacular growths of Agaricia tenuifolia with some Porites divaricata, Millepora alcicornis, and Acropora cervicornis that covered the outer slope of the ridge across the western entrance are dead and partly covered by the encrusting sponge Chondrilla $\mathrm{cf}$. nucula (Fig. 6). The inner slope has an even denser cover of $C$. cf. nucula, Zoanthus sp., and Halimeda opuntia over coral rubble. The crest supports a few live colonies of $P$. divaricata being encroached upon by zoanthid mats and encrusting sponges (Fig. 7).

A quick check for the live $P$. divaricata reported on the eastern rim opposite the entrance 
revealed only dead colonies, still in growth position and encrusted by $C$. cf. nucula. However, a few small live colonies of Porites astreoides were found attached to mangrove roots.

On the southern rim, only traces of live $P$. divaricata and $P$. astreoides were found, now overgrown by vigorous colonies of Zoanthus sp. (Fig. 8).

\section{Pond D, Manatee Cay}

The Thalassia-covered low ridge across the western entrance to this pond still supports healthy colonies of Manicina aerolata (Fig. 9) and Porites divaricata.

Along the north rim, $P$. divaricata is struggling to survive an overgrowth of zoanthids, Halimeda opuntia, and anemones (Fig. 10). The large Siderastraea siderea colony earlier reported on this north rim is still alive but clearly competing with zoanthid mats, encrusting $C$. cf. nucula, and algal growth (Fig. 11). High turbidity inside this pond impeded observations.

Pond E, Fisherman's Cay

The shallow north end of the ridge across the entrance to this pond still supports live colonies of Porites divaricata (Fig. 12a) and Manicina aerolata on a sandy Thalassia-covered bottom. By contrast, the deeper southern crest, which was originally covered by a flourishing coral community dominated by Agaricia tenuifolia, has no live corals. Most of the dead colonies are still in growth position and are encrusted by the sponge Chondrilla cf. nucula and overgrown by Halimeda opuntia (Fig. 12b).

Small live colonies of $P$. divaricata on peat banks and $P$. astreoides on mangrove roots were found on both the southern and eastern rims. The large colony of Siderastraea siderea previously reported from the north end of the pond is still flourishing there.

\section{DISCUSSION}

Though brief, the visits to Ponds A, C, D, and E in 1999 revealed that the 1998 bleaching event caused major changes in the benthic communities of the Pelican Cays ponds. There has been a drastic loss of coral cover, with only a few scattered live colonies of hardier species surviving, including Porites divaricata, P.astreoides, Colpophyllia natans, Siderastraea siderea, and Montastraea annularis. The most vulnerable corals have been Agaricia tenuifolia, Acropora cervicornis, and the hydrocoral Millepora alcicornis: no live colonies of these species were found in the ponds or on the outer flanks of ridges across the entrances.

Sponges, colonial zoanthids, and algae have benefited from this demise of the corals and are flourishing on the recently dead skeletons. Some are even growing over the coral remnants that are still alive. Among the sponges, the encrusting Chondrilla cf. nucula is the most noticeably abundant organism, accompanied by extensive mats of Zoanthus sp. and heavy growths of the green algae Halimeda opuntia and Caulerpa racemosa.

More detailed observations planned for the near future will document this change more accurately and possibly provide a sense of the long-term trends in the species composition of the benthic communities of the Pelican Cays ponds. 


\section{REFERENCES}

Aronson, R. B., and W. F. Precht

1997. Stasis, biological disturbance, and community structure of a Holocene coral reef. Paleobiology 23:326-346.

Aronson, R. B., W. F. Precht, I. G. Macintyre, and T. J. T. Murdoch

2000. Coral Bleach-Out in Belize. Nature. (In press). 


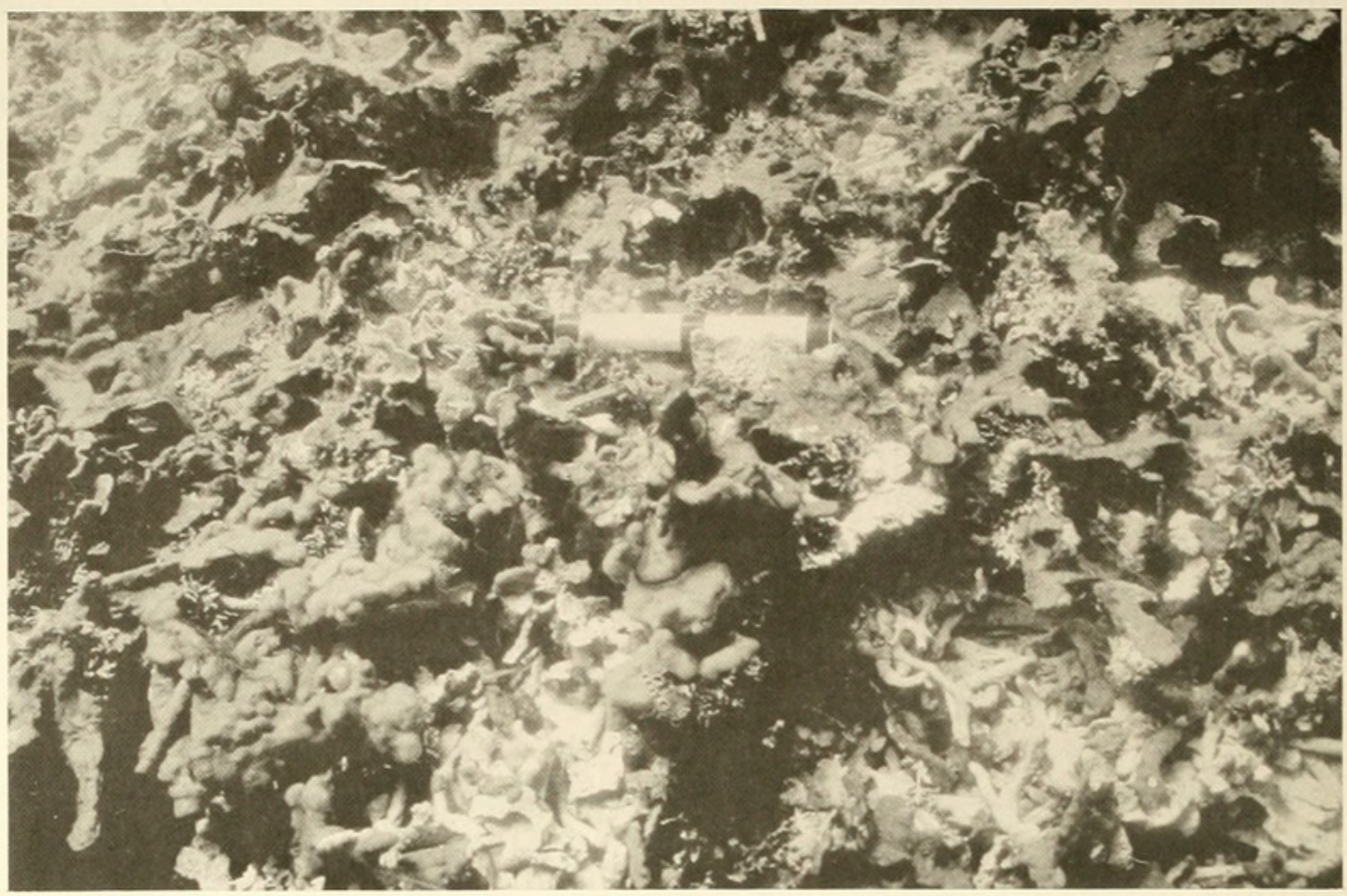

Figure 1. Pond A - Cat Cay. Outer flank of ridge across western entrance. Dead Agaricia tenuifolia extensively encrusted by Chondrilla $\mathrm{cf}$. nucula and surrounded by growths of Halimeda opuntia. Scale $=20 \mathrm{~cm}$. June 13, 1999 .

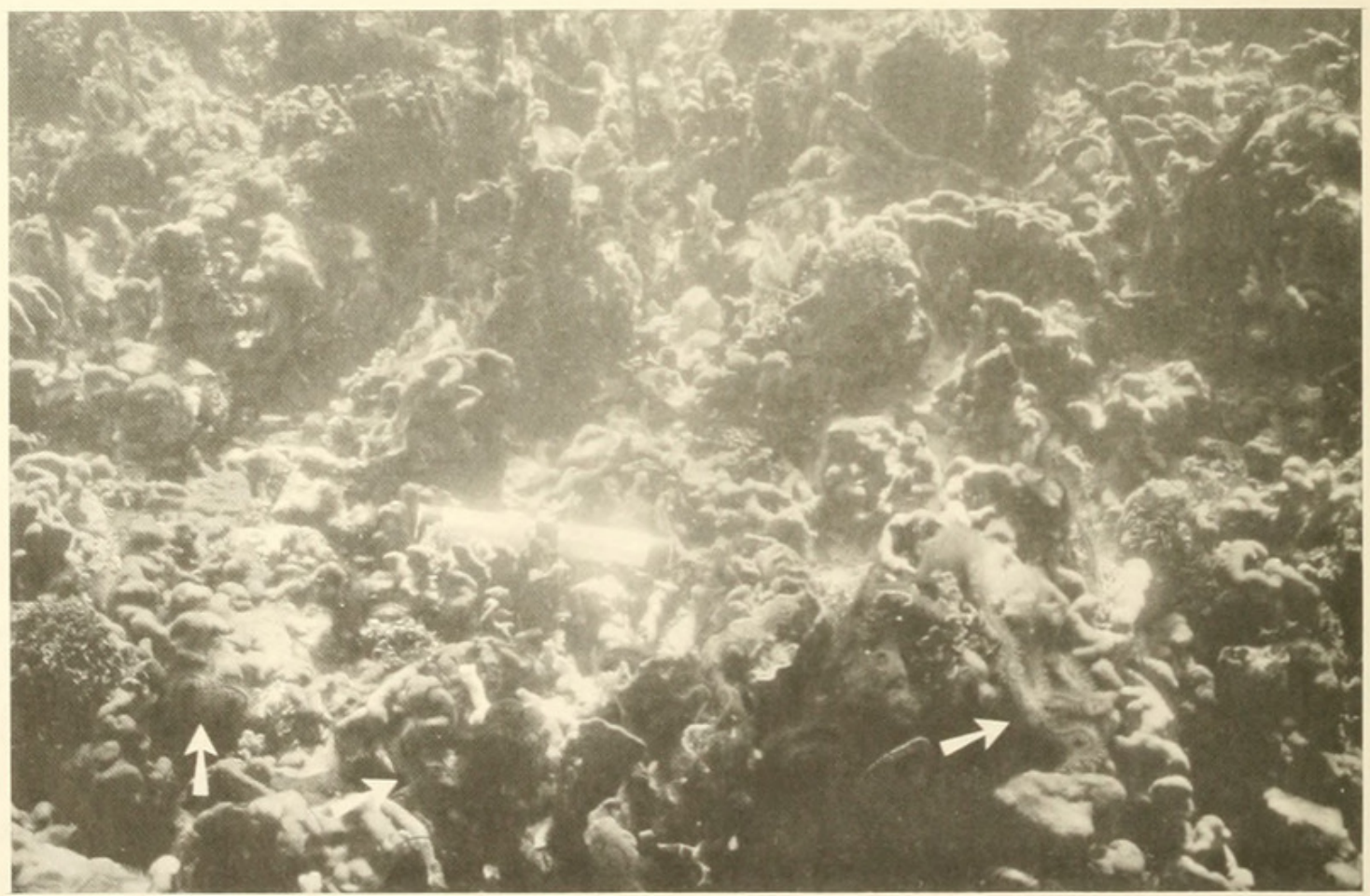

Figure 2. Pond A - Cat Cay. Inner flank of ridge across western entrance. Very extensive cover of encrusting sponge Chondrilla cf. nucula over coral rubble. Note scattered growths of Halimedia opuntia and abundance of brittle stars (arrows). Scale $=20 \mathrm{~cm}$. June 13, 1999 . 

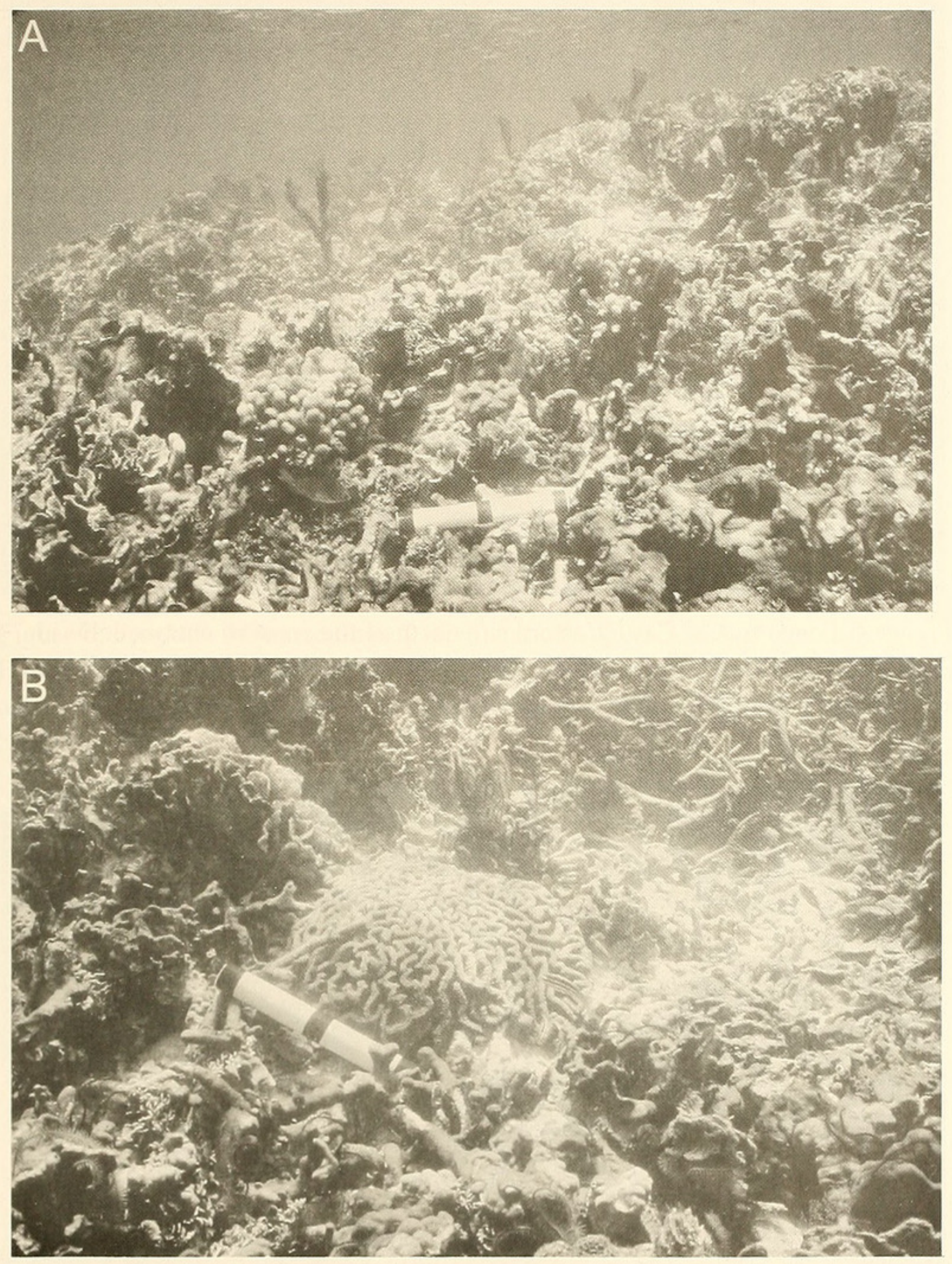

Figure 3. Pond A - Cat Cay. Crest of ridge across western entrance. A) Patches of live Porites divaricata on a bottom consisting of dead coral encrusted by Chondrilla cf. nucula. B) Live colony of Colpophyllia natans surrounded by dead coral encrusted by $C$. cf. nucula and packed with Halimeda opuntia.

Scale $=20 \mathrm{~cm}$. June 13, 1999 . 


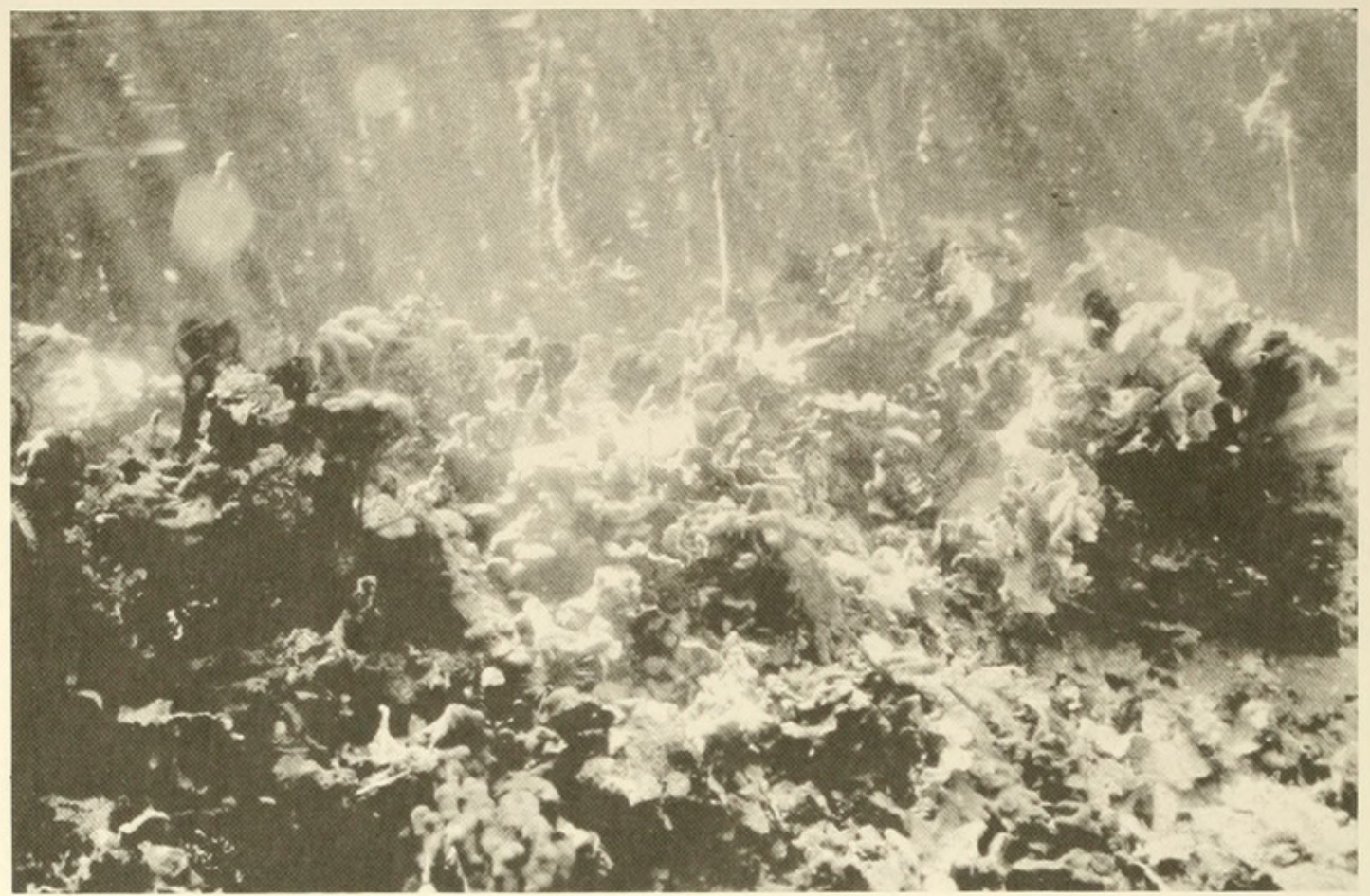

Figure 4. Pond A - Cat Cay. Western rim north of the western entrance. Dead Agaricia tenuifolia partly covered by Chondrilla cf. nucula, Halimeda opuntia, and mats of colonial Zoanthus sp. Scale $=20 \mathrm{~cm}$. June 13, 1999.

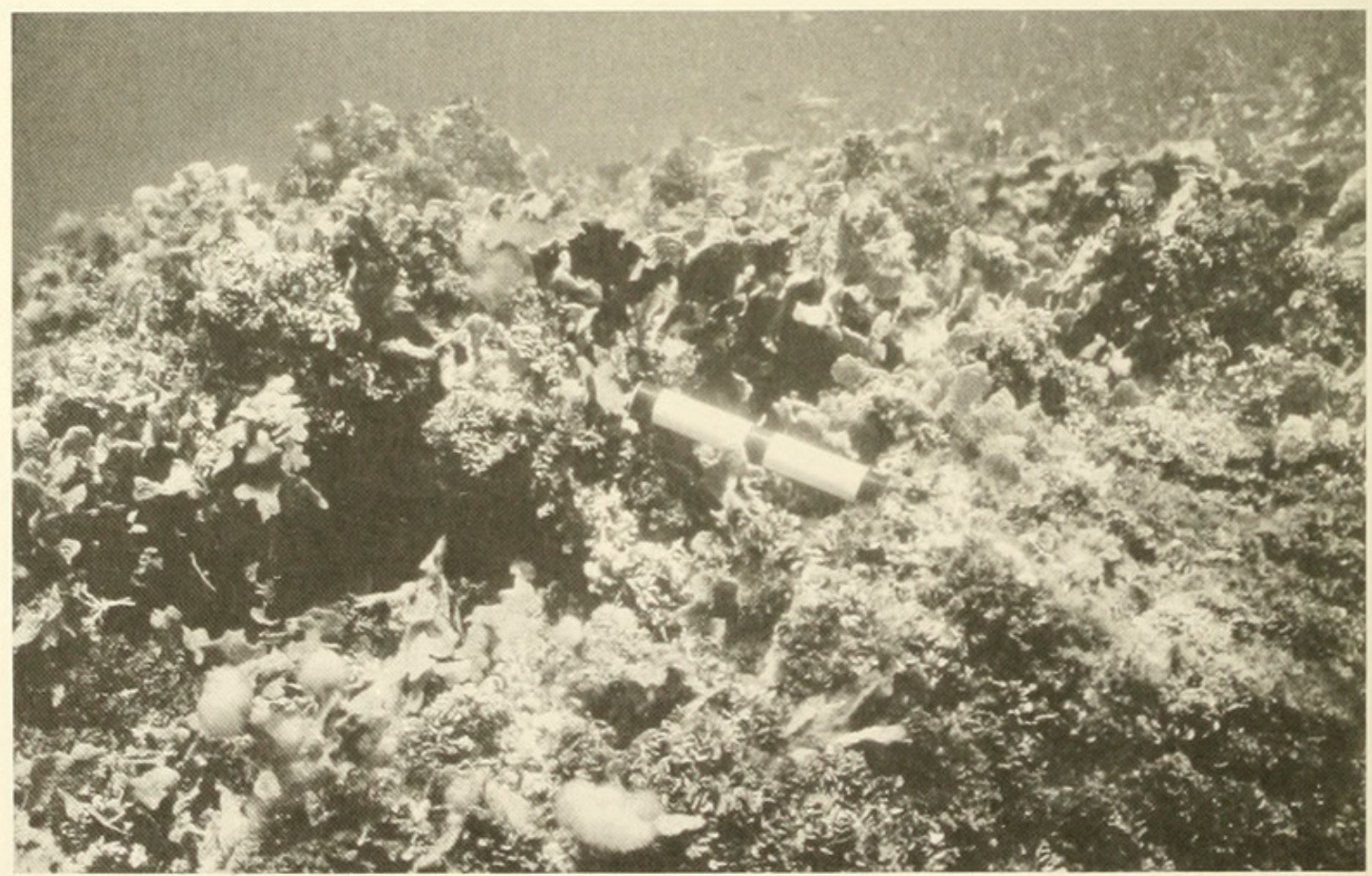

Figure 5. Pond A - Cat Cay. Formerly coral-rich area around a small mangrove island at the southern end of this pond. Dead Agaricia tenuifolia being overgrown by Halimeda opuntia and tufts of filamentous blue-green algae. Scale $=20 \mathrm{~cm}$. June 13, 1999. 


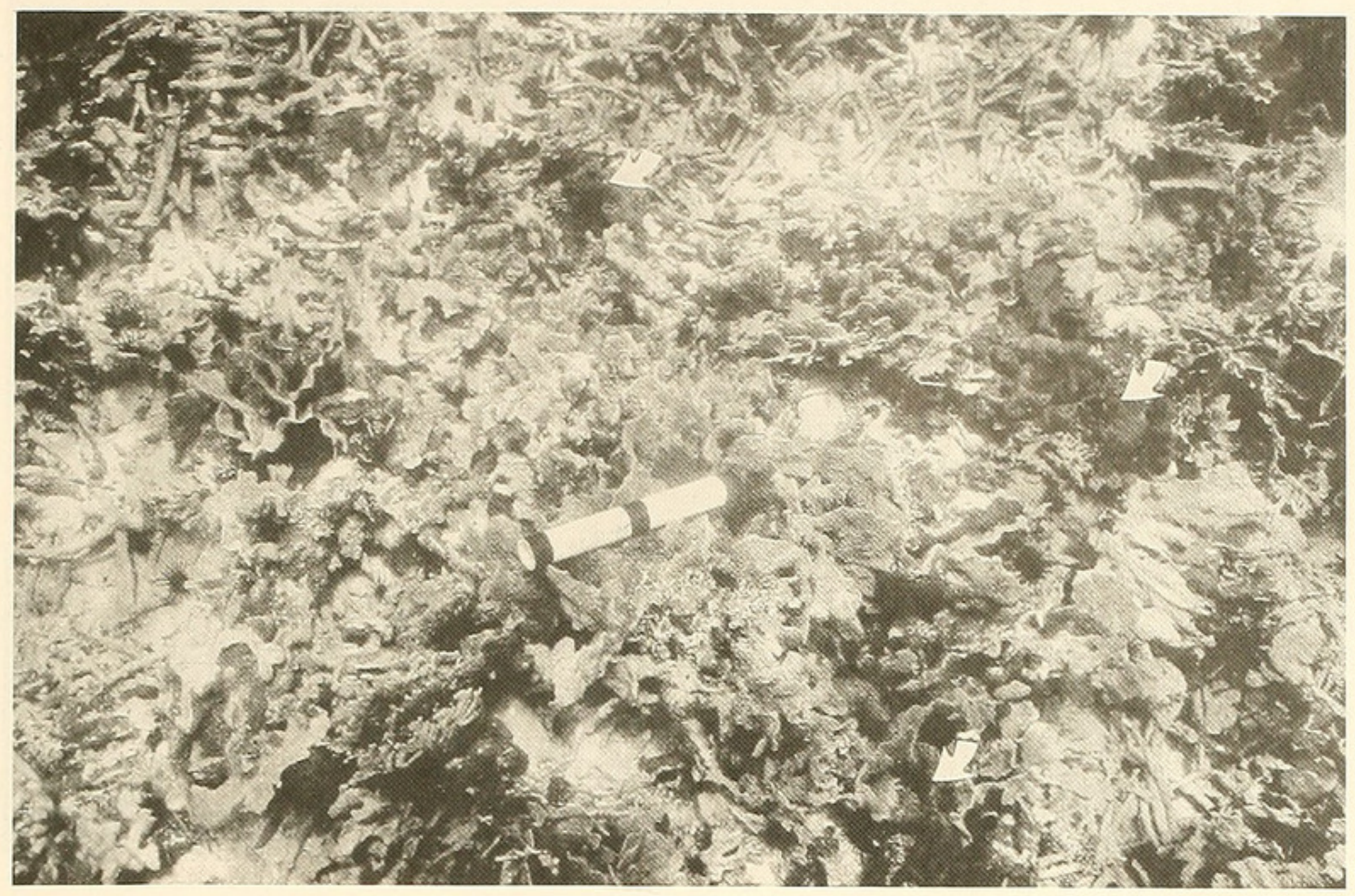

Figure 6. Pond C - Manatee Cay. Outer flank of ridge across western entrance. Dead coral bottom -- mostly Agaricia tenuifolia with some Acropora cervicornis and Millepora alcicornis. Patchy encrustations of Chondrilla $\mathrm{cf}$. nucula (arrows). Scale $=20 \mathrm{~cm}$. June 13, 1999.

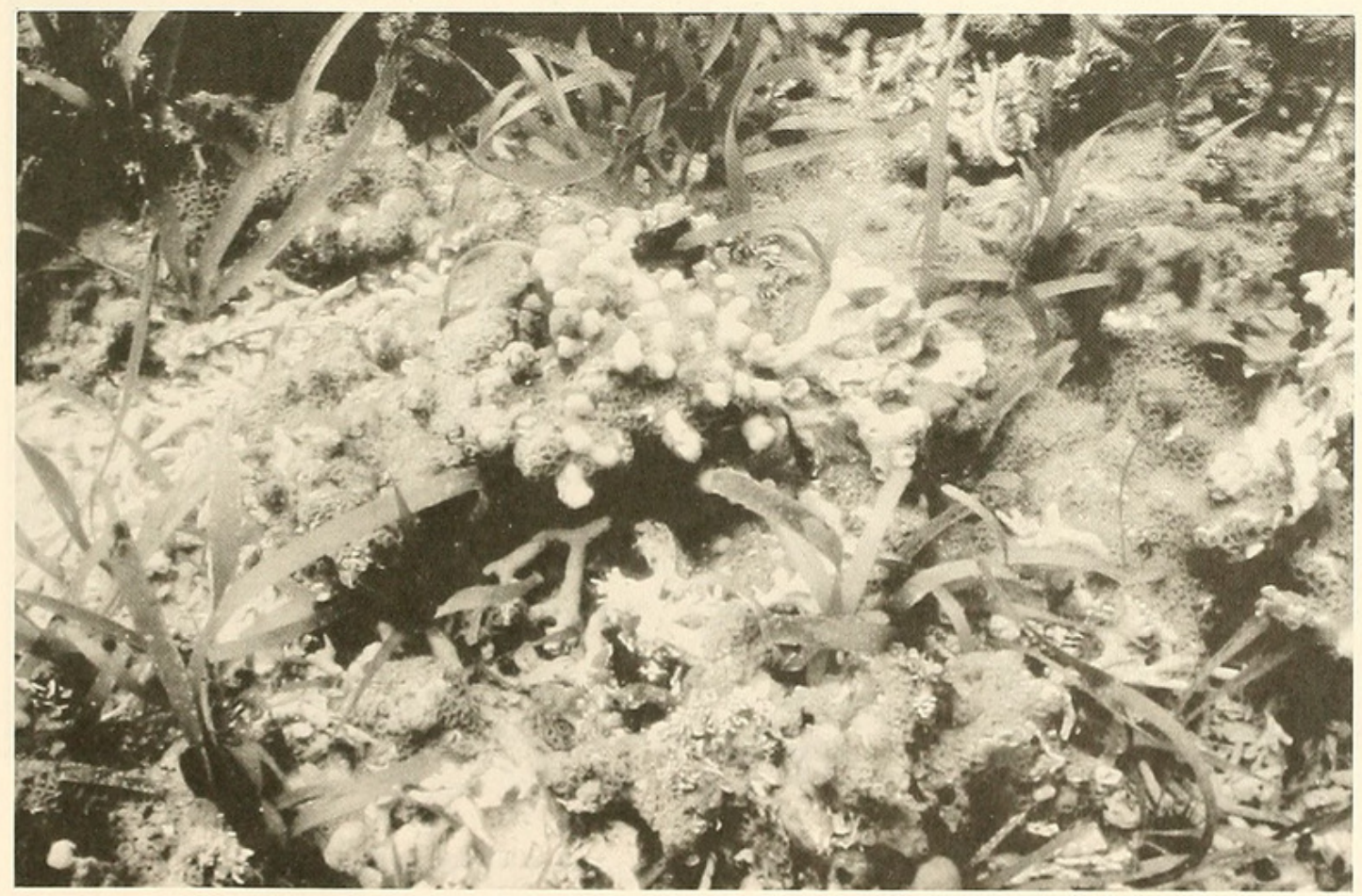

Figure 7. Pond C - Manatee Cay. Crest of ridge across western entrance. Live Porites divaricata almost smothered by encrusting colonial Zoanthus sp. and Chondrilla cf. nucula. June 15, 1999. 


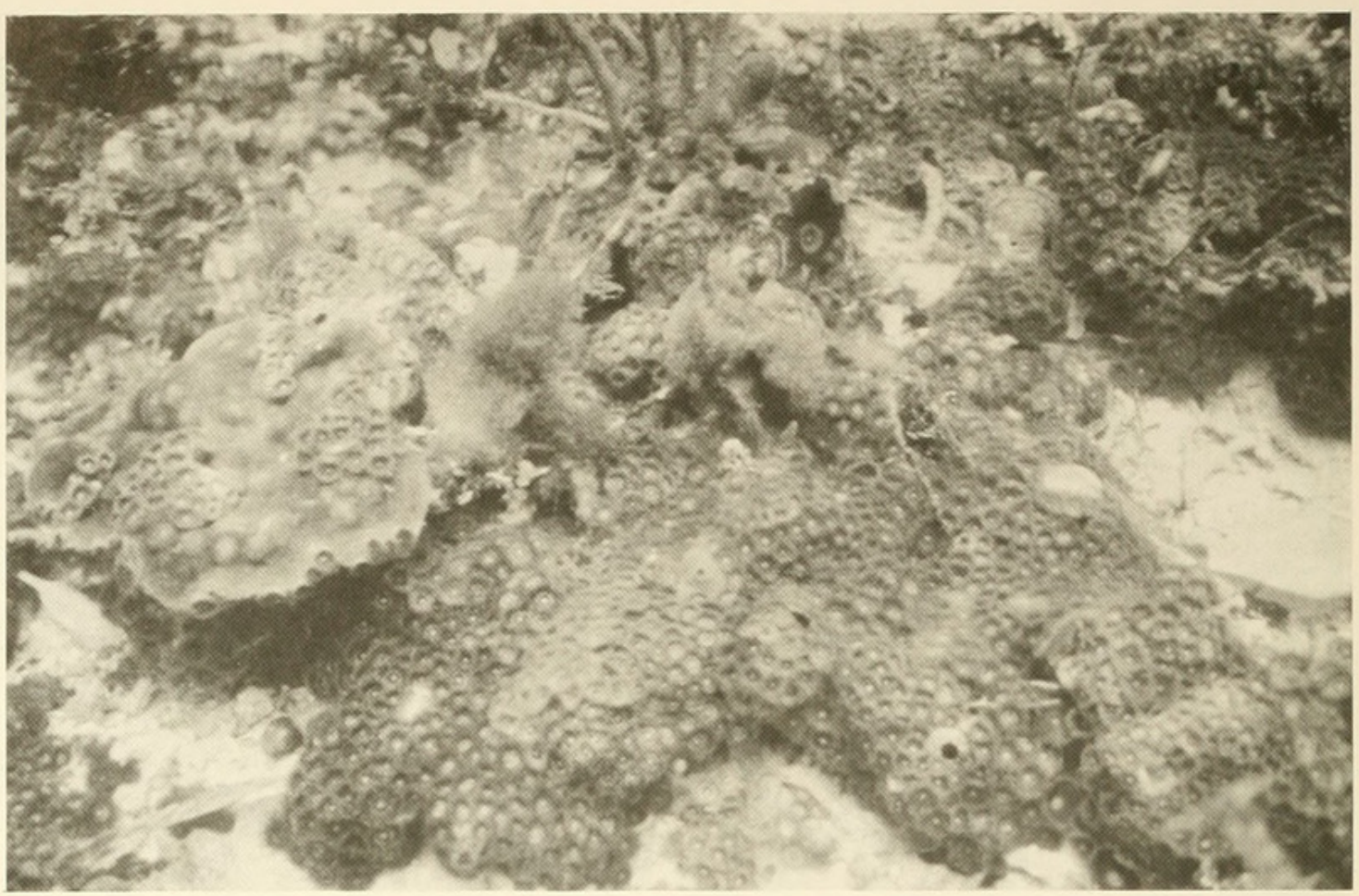

Figure 8. Pond C - Manatee Cay. Southern rim of this pond. Live Porites astreoides almost overgrown by colonial Zoanthus sp. June 15, 1999.

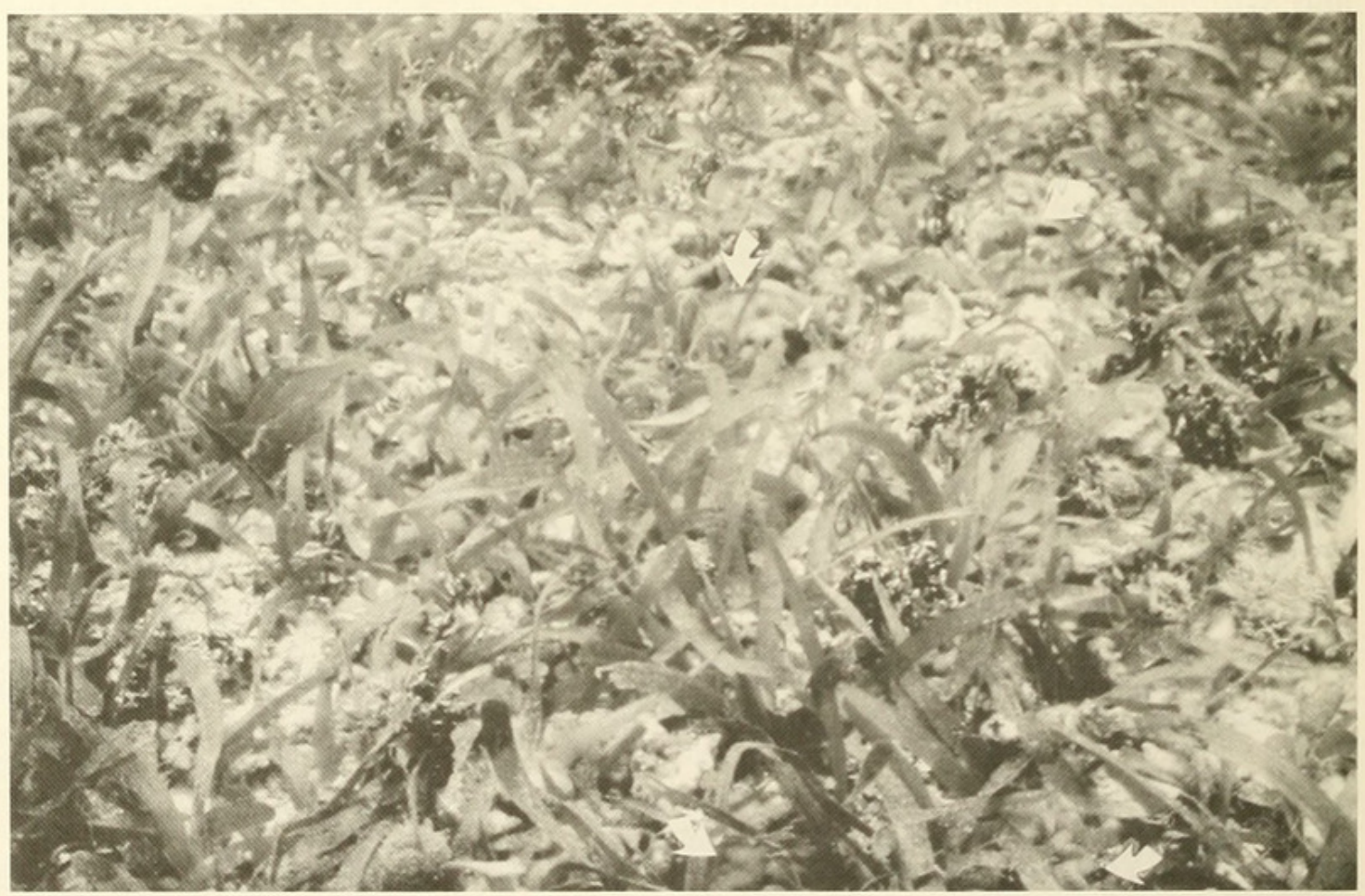

Figure 9. Pond D - Manatee Cay. Crest at north end of ridge across entrance. Live Manicina aerolata (arrows) on a Thalassia/coral rubble bottom. June 15, 1999. 


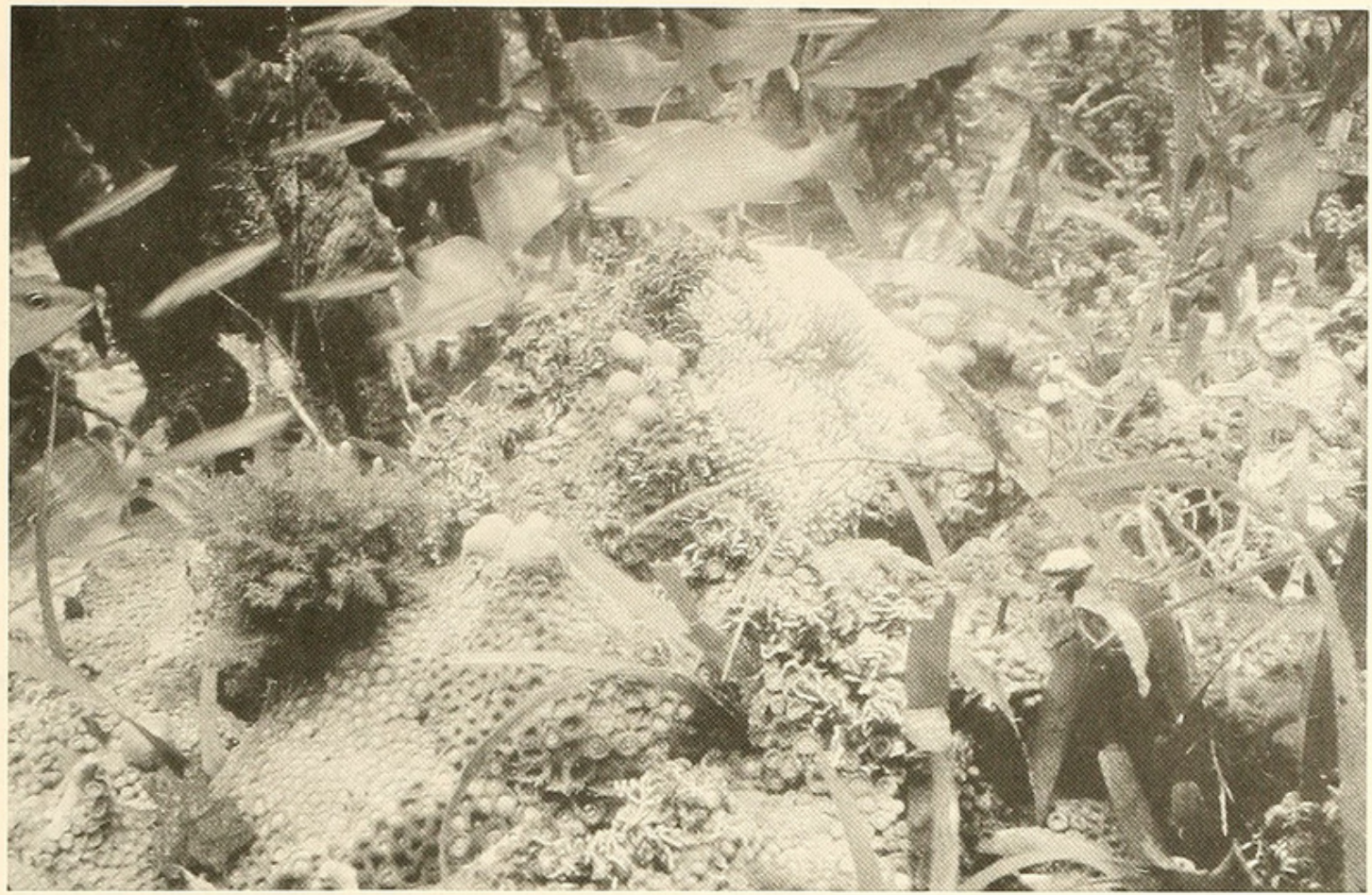

Figure 10. Pond D - Manatee Cay. North rim of this pond near the entrance. Tips of live Porites divaricata poke up through a cover of colonial Zoanthus sp., Halimeda opuntia, and an anemone. June 15, 1999.

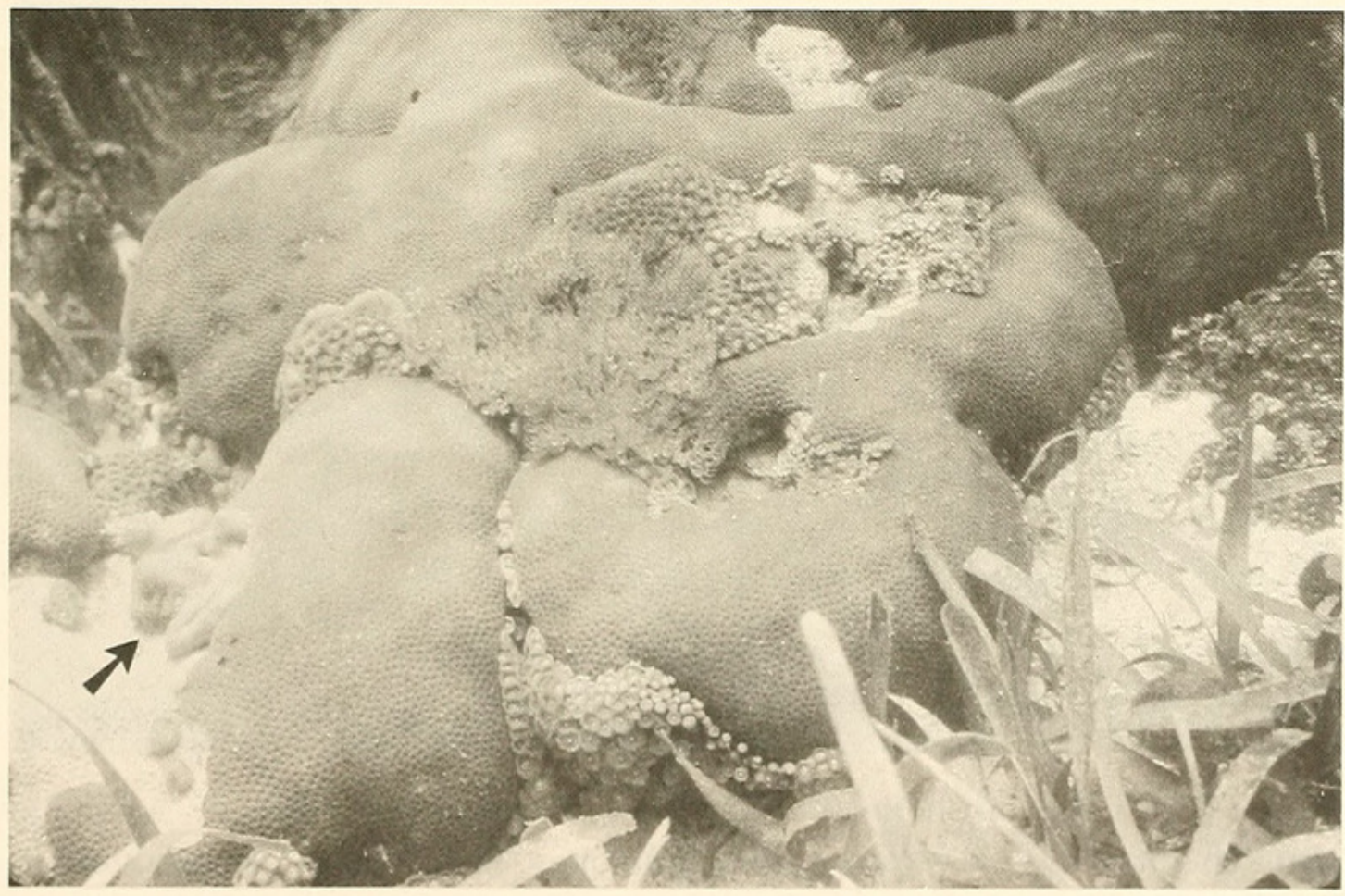

Figure 11. Pond D - Manatee Cay. North rim of this pond. Large live colony of Siderastraea siderea coping with attached Zoanthus sp., Chondrilla $\mathrm{cf}$. nucula (arrow), and macroscopic algae. June 15, 1999. 

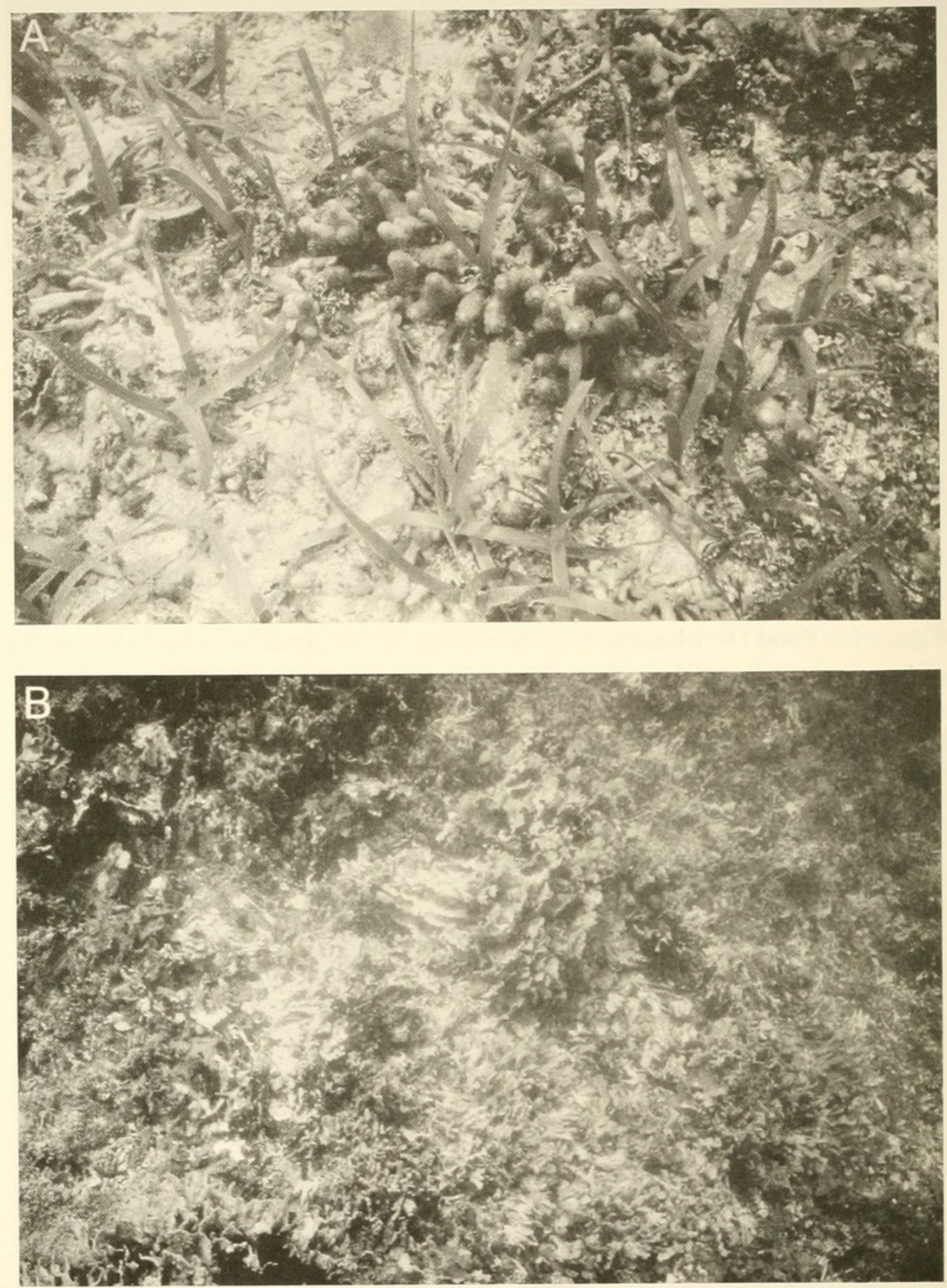

Figure 12. Pond E - Fisherman's Cay. Crest of ridge across entrance. A) Shallow north end of ridge. Live Porites divaricata on a Thalassia/Halimeda bottom. B) Deeper south end of this ridge. Dead Agaricia tenuifolia, mostly in growth position, encrusted by Chondrilla cf. nucula and surrounded by Halimeda opuntia. June 15, 1999. 


\section{$2 \mathrm{BHL}$ Biodiversity Heritage Library}

Macintyre, Ian G et al. 2000. "A general biological and geological survey of the rims of ponds in the major mangrove islands of the Pelican Cays, Belize." Atoll research bulletin $467,13-44$.

View This Item Online: https://www.biodiversitylibrary.org/item/123419

Permalink: https://www.biodiversitylibrary.org/partpdf/83124

\section{Holding Institution}

Smithsonian Libraries

\section{Sponsored by}

Biodiversity Heritage Library

\section{Copyright \& Reuse}

Copyright Status: In Copyright. Digitized with the permission of the rights holder Rights Holder: National Museum of Natural History, Smithsonian Institution License: https://creativecommons.org/licenses/by-nc-sa/4.0/ Rights: http://www.biodiversitylibrary.org/permissions/

This document was created from content at the Biodiversity Heritage Library, the world's largest open access digital library for biodiversity literature and archives. Visit BHL at https://www.biodiversitylibrary.org. 